\title{
Silicate Glass-Based Nanocomposite Scintillators
}

\author{
Martin Nikl1, Daniel Nižňanský², Jakub Ruzicka², \\ Carla Cannas ${ }^{3}$ and Takayuki Yanagida ${ }^{4}$ \\ ${ }^{1}$ Institute of Physics, Academy of Sciences of the Czech Republic \\ ${ }^{2}$ Faculty of Science, Charles University of Prague, Department of Inorganic Chemistry \\ ${ }^{3}$ University of Cagliari, Chemistry department \\ ${ }^{4}$ New Industry Creation Hatchery Center, Tohoku University \\ ${ }^{1,2}$ Czech Republic \\ ${ }^{3}$ Italy \\ ${ }^{4}$ Japan
}

\section{Introduction}

Scintillation materials are employed to detect X-ray and gamma-ray photons, neutrons or accelerated particles. Usually the wide band-gap insulator materials of a high degree of structural perfection are used in the form of artificially made single crystals. They accomplish fast and efficient transformation of incoming high energy photon/particle into a number of electron-hole pairs collected in the conduction and valence bands, respectively, and their radiative recombination at suitable luminescence centres in the material. Generated UV or visible light can be then detected with high sensitivity by conventional solid state semiconductor- or photomultiplier-based photodetectors, which are an indispensable part of scintillation detectors.

Development of scintillation materials was stimulated by the discoveries of X-rays in 1895 (Röntgen, 1896) and natural radioactivity of uranium and other elements soon after that (Becquerel, 1896; Curie, 1898). A simple photographic film was found rather inefficient for their detection. As a result, the search for materials able to convert $X(\gamma)$ rays to visible rays started immediately in order to couple them with sensitive photographic film-based detectors. $\mathrm{CaWO}_{4}$ and $\mathrm{ZnS}$-based powder phosphors were used for this purpose for a long time. But the development of true bulk single crystal scintillators started only at the end of 1940s when Tl-doped $\mathrm{NaI}$ and $\mathrm{CsI}$ and $\mathrm{CdWO}_{4}$ crystals were reported to be applicable for scintillation detection (Weber, 2002).

As mentioned above, scintillation detectors were mainly based on single crystal materials. Despite their best figure-of-merit, by far not all intrinsically efficient compounds can be grown in the form of the bulk single crystals of the sufficient size and manufacturing costs acceptable for practical applications. Too high melting temperatures, the presence of phase transitions between the melting point and room temperature (RT), or stoichiometry problems arising from different volatility of binary constituents from the high temperature melt of complex compounds are just a few examples of problems potentially disabling a 
single crystal preparation. In less demanding applications the suitably doped glasses are also used. However, their efficiency and stability in the radiation environment is usually much inferior to the single crystal systems. Modern technologies bring new material conceptions, e.g. the optical ceramics which found its use in the Computed Tomography medical imaging (Greskovich \& Duclos, 1997; van Eijk, 2002).

Most recently, an innovative approach was reported consisting in preparation of composite materials composed of an inorganic scintillating phase embedded in an inert optical organic or inorganic material. However, the refractive index change between the two phases can result in scattering phenomena and transparency degradation. To diminish such a problem the active scintillator phase has to be scaled down to few tens of nanometers size, because then the visible light scattering is considerably reduced. Scaling down the crystalline phase to nano-metric size can change physical properties of the material itself and can offer a unique combination of optical, luminescence and scintillation characteristics which cannot be obtained in a bulk single phase material. While semiconductor nanocrystals have been a subject of study for more than thirty years, investigations of wide band-gap insulating nanocrystals begun only recently (Tissue, 1998; Meltzer et al., 1998). Nanocrystals of $\mathrm{Y}_{2} \mathrm{O}_{3}$ doped with europium or terbium were produced by condensation from gas phase (Bihari et al., 1997; Meltzer et al., 1999), sol-gel (Goldburt et al., 1997) or combustion (Muenchausen et al., 2007) methods. $\mathrm{Gd}_{2} \mathrm{O}_{3}$ :Eu was produced by sol-lyophilization (Louis et al., 2003; Mercier et al., 2004, 2006) and CBD (Cluster Beam Deposition) (Mercier et al, 2007) techniques. The band gap increase of a crystal due to exciton quantum confinement is a well known phenomenon in direct gap semiconductors like GaAs, GaN or CdSe. To a lesser extent, similar increase is observed also in insulating $\mathrm{Gd}_{2} \mathrm{O}_{3}$ :Eu nanocrystals (Mercier et al., 2007). In this material the reduced size can strongly influence the relative population of the dopant energy levels and the width of emission lines (Mercier et al., 2006); moreover, the presence of dopant ions on the nanocrystal surface can be evidenced by appearance of a specific emission band (Mercier et al., 2004). Luminescence efficiency can also be affected by quantum confinement; in fact, in $\mathrm{Y}_{2} \mathrm{O}_{3}: \mathrm{Tb}$ an increase of $\mathrm{Tb}^{3+}$ luminescence efficiency is observed by reducing particle size probably because of the decrease of non-radiative recombination phenomena (Goldburt et al., 1997). Moreover, the fluorescence time decay is strongly affected by refractive index of the inert host material (Meltzer et al., 1999) and quenching phenomena are shifted towards higher concentrations with respect to the single crystal (Muenchausen et al., 2007).

Among reported attempts on preparation of such nanocomposite systems the fluoro-clorozirconate glass-ceramic can be mentioned: luminescence arises at $\mathrm{Eu}^{2+}$-containing $\mathrm{BaCl}_{2}$ nanocrystals with average size of $14 \mathrm{~nm}$, thus, the material possesses good transparency (Johnson et al., 2006). CdTe nanoparticles show an efficient luminescence when embedded in BaFBr:Eu (Chen et al., 2006). Nanoporous silica matrix impregnated by CdSe/ZnS luminescent nanoparticles or rhodamine dye shows also intense emission (Létant et al., 2006a, 2006b). Multiple quantum wells hybrid structures, where semiconducting $\mathrm{PbI}_{4}$ layers are alternated with organic insulating ones, have shown superfast efficient luminescence (390 ps) due to excitonic superradiance and quantum confinement effect which might allow them to be used as ultra-fast scintillators (Shibuya et al., 2004).

Scintillation properties of the Ce-doped rare-earth orthosilicates were mentioned for the first time in early 1980s in the study dealing with the $\mathrm{Gd}_{2} \mathrm{SiO}_{5}$ :Ce (GSO) (Takagi et al., 1983). Following studies concerned mainly $\mathrm{Lu}_{2} \mathrm{SiO}_{5}: \mathrm{Ce}$ (LSO) (Suzuki et al., 1992) and mixed $\mathrm{Lu}_{2-}$ 
${ }_{x} \mathrm{Y}_{x} \mathrm{SiO}_{5}$ :Ce (LYSO) (Cooke et al., 2000) which became materials of choice for PET imaging in medicine. Single crystals of these orthosilicate materials were prepared by the Czochralski method using radio-frequency (RF) heating due to very high melting point of these compounds (between $\sim 1950-2150^{\circ} \mathrm{C}$ ) (Melcher et al., 1993). The growth of single crystals of another stoichiometry in the $\mathrm{SiO}_{2}-\mathrm{RE}_{2} \mathrm{O}_{3}$ system, namely $\mathrm{RE}_{2} \mathrm{Si}_{2} \mathrm{O}_{7}$, was reported also in early 1980's and basic optical and luminescence characteristics were explored (BretheauRaynal et al., 1980; Vakhidov et al., 1981). However, scintillation characteristics of Ce-doped single crystals of $\mathrm{Lu}_{2} \mathrm{Si}_{2} \mathrm{O}_{7}$ (LPS) started to be studied only in last decade (Pauwels et al., 2000). LPS:Ce has shown similar light yield and other scintillation characteristics as LSO:Ce, but no afterglow at RT was found due to the absence of TSL peaks close to RT which is a substantial advantage of this material (Pidol et al., 2007). Very recently also single crystal of YPS:Ce was grown and its scintillation properties were characterized (Feng et al., 2010).

Several different methods were reported for the preparation of powder silicate phosphors which were considered for another applications like FED or cathodoluminescence screens (Holloway et al., 1999). Meijerink et al. (Meijerink et al., 1991) used the classic solid-state sintering to synthetize YSO:Ce. Kang et al. employed method of spray pyrolysis (Kang et al., 1999 ) which provides samples with better homogeneity. Combustion synthesis (GonzalezOrtega et al., 2005), hydrothermal (Cooke et al., 2006) and sol-gel (Marsh et al., 2002; Jiao et al., 2007) methods were also employed in order to reduce too high temperatures necessary for the preparation. Using pulsed laser deposition, YSO:Ce thin films were prepared and studied (Coetsee et al., 2007). Ce-doped lutetium pyrosilicate synthesis and photoluminescence characteristics were published recently (Sokolnicki et al., 2009).

The sol-gel methods are well applicable to silicate-based synthesis due to stability of TEOS (tetraethoxysilane) which is used as an Si precursor. However, final results depend on many parameters like the temperature of gelation, type of solvent, use of the additives etc. The additives like formamide influence the surface tension in the pores (Brinker \& Scherer, 1990) and help to prepare crack-free monolite samples. They participate in chemical reactions during the stages of hydrolysis and gelation (Niznansky \& Rehspringer, 1995) and they also influence the phase evolution during heat treatment (Niznansky et al., 2001).

\subsection{Phase diagram $\mathrm{Y}_{2} \mathrm{O}_{3}-\mathrm{SiO}_{2}$}

Yttrium and lutetium silicates have similar phase diagram which is shown in Fig. 1.

It follows from Fig. 1 that two stoichiometric compounds, $\mathrm{RE}_{2} \mathrm{SiO}_{5}$ and $\mathrm{RE}_{2} \mathrm{Si}_{2} \mathrm{O}_{7}(\mathrm{RE}=\mathrm{Y}$, $\mathrm{Lu}$ ), are stable at RT. Second important conclusion is the presence of the region with limited miscibility of $\mathrm{SiO}_{2}$ and $\mathrm{RE}_{2} \mathrm{Si}_{2} \mathrm{O}_{7}$ which is a condition favourable to preparation of $\mathrm{RE}_{2} \mathrm{Si}_{2} \mathrm{O}_{7}$ nanocomposite in the silica matrix.

\subsection{Structure of pyrosilicate}

YPS crystallizes in several crystalographic forms. $\mathrm{a}-\mathrm{Y}_{2} \mathrm{Si}_{2} \mathrm{O}_{7}$ crystallizes in the triclinic P-1 space group $\left(a=6.59 \AA, b=6.64 \AA, c=12.25 \AA, a=94^{\circ}, \beta=89^{\circ}, \gamma=93^{\circ}\right.$ ) (Liddell \& Thompson, 1986) at the temperature of $1100{ }^{\circ} \mathrm{C}$. $\beta-\mathrm{Y}_{2} \mathrm{Si}_{2} \mathrm{O}_{7}$ is isotypic with thortveitite, $\mathrm{Sc}_{2} \mathrm{Si}_{2} \mathrm{O}_{7}$, and crystallizes in the $C 2 / m$ space group $\left(a=6,83 \AA, b=8,97 \AA, c=4,72 \AA, \beta=101^{\circ}\right.$ ) (Redhammer \& Roth, 2003). $\mathrm{Y}^{3+}$ cation occupies a distorted octahedral site with $\mathrm{Y}-\mathrm{O}$ bond lengths in the range 2.239 (2)-2.309 (2) $\AA$. The $\mathrm{SiO}_{4}$ tetrahedron is regular with $\mathrm{Si}-\mathrm{O}$ bond lengths in the range 1.619 - $1.630 \AA$. Monoclinic $\mathrm{C} 2 / \mathrm{m}$ phase was obtained after heat treatment at $1300^{\circ} \mathrm{C}$. $\gamma-\mathrm{Y}_{2} \mathrm{Si}_{2} \mathrm{O}_{7}$ was found to crystallize in the monoclinic $\mathrm{P} 2_{1} / c$ space group (Leonyuk et al., 1999) 
and its lattice parameters are $a=4.694 \AA, b=10.856 \AA, c=5.588 \AA, \beta=96.01^{\circ}$. According to Dias et al. (Dias et al., 1990) the structure of high temperature phase $\delta-\mathrm{Y}_{2} \mathrm{Si}_{2} \mathrm{O}_{7}$ has the orthorhombic space group Pnam ( $a=13.81 \AA$, b=5.02 $\AA$, c=8.30 $\mathrm{A}$ ).

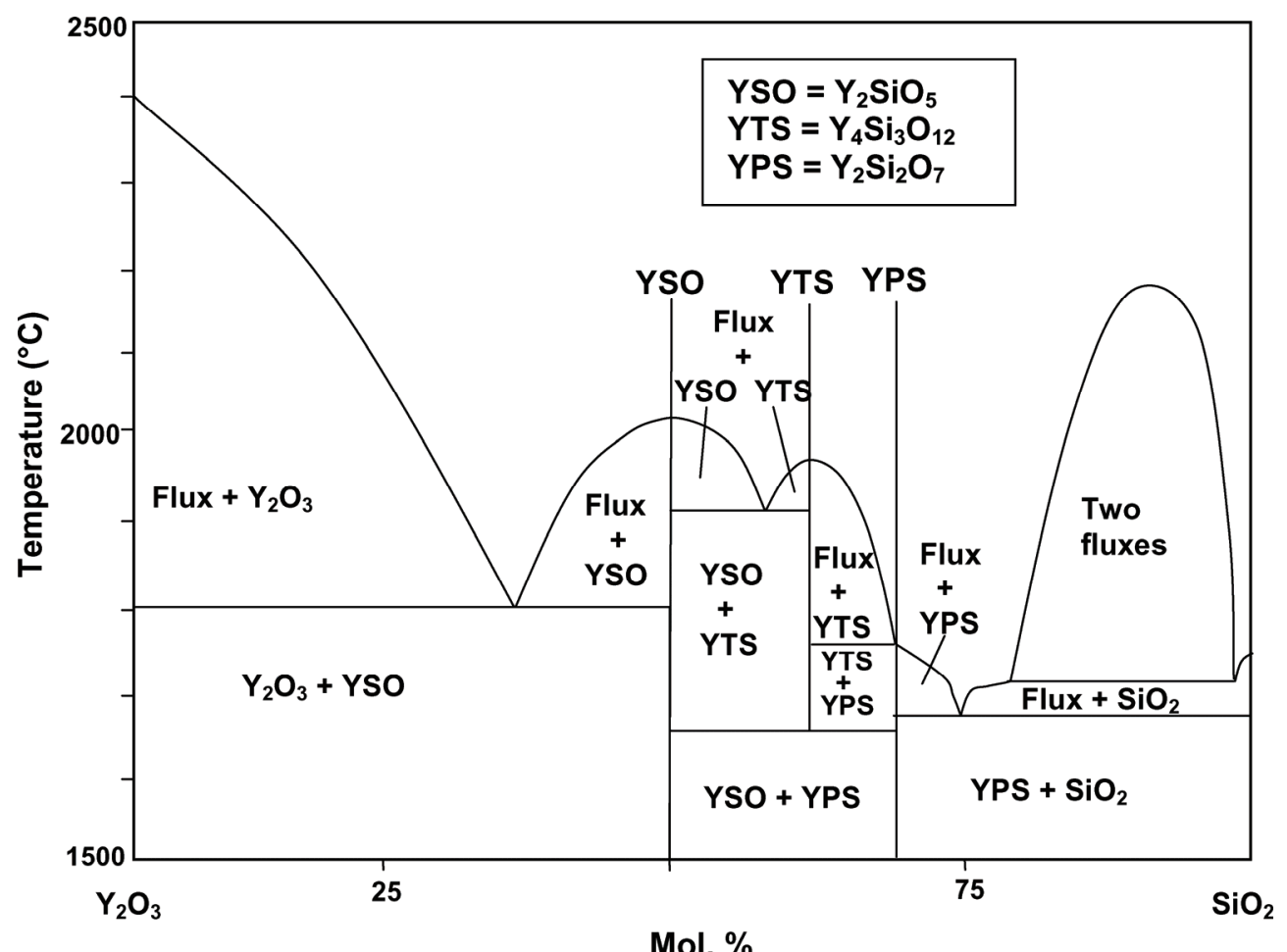

Fig. 1. Phase diagram of $\mathrm{Y}_{2} \mathrm{O}_{3}-\mathrm{SiO}_{3}$ system

$\mathrm{Lu}_{2} \mathrm{Si}_{2} \mathrm{O}_{7}$ has one stable crystallographic phase at $\mathrm{RT}$ representing the thorveitite structure with monoclinic symmetry, space group $\mathrm{C} 2 / \mathrm{m}$. It has a single crystallographic site for lutetium ions with six oxygen neighbours. It is a distorted octahedral site with C2 symmetry (Bretheau-Raynal et al., 1980; Soetebier et al., 2002).

This monoclinic structure can be briefly described as a stacking of alternating parallel layers of $\left[\mathrm{LuO}_{6}\right]$ octahedral sharing edges and isolated $\left[\mathrm{Si}_{2} \mathrm{O}_{7}\right]$ groups. $\left[\mathrm{Si}_{2} \mathrm{O}_{7}\right]$ groups are formed by two $\left[\mathrm{SiO}_{4}\right]$ tetrahedra sharing oxygen, $\mathrm{Si}-\mathrm{O}-\mathrm{Si}$ bond angle between tetrahedra is equal to $180^{\circ}$, see Fig. 2 . The layers of $\left[\mathrm{Si}_{2} \mathrm{O}_{7}\right]$ groups are organized this way: $\mathrm{Si}$ atom of the $\left[\mathrm{Si}_{2} \mathrm{O}_{7}\right]$ group shares one oxygen atom from the $\left[\mathrm{LuO}_{6}\right]$ layer above and two from the one below in the c-direction, the $\mathrm{Si}$ atom from the opposite side is in a reverse situation (Yan et al., 2006). In this chapter, we describe the preparation of $\mathrm{RE}_{2} \mathrm{Si}_{2} \mathrm{O}_{7}$ ( $\mathrm{RE}=\mathrm{Y}$ (YPS), Lu (LPS)) compounds doped by Ce ions in powder form using the sol-gel method. XRD and SEM are employed to check the crystal structure, luminescence spectra and decays are measured to characterize $\mathrm{Ce}^{3+}$ ion emission in an LPS host. Furthermore, we prepare nanocomposites of Ce-doped $\mathrm{RE}_{2} \mathrm{Si}_{2} \mathrm{O}_{7}$ in the silica matrix and use XRD, SEM, HRTEM and luminescence techniques for their characterization. 


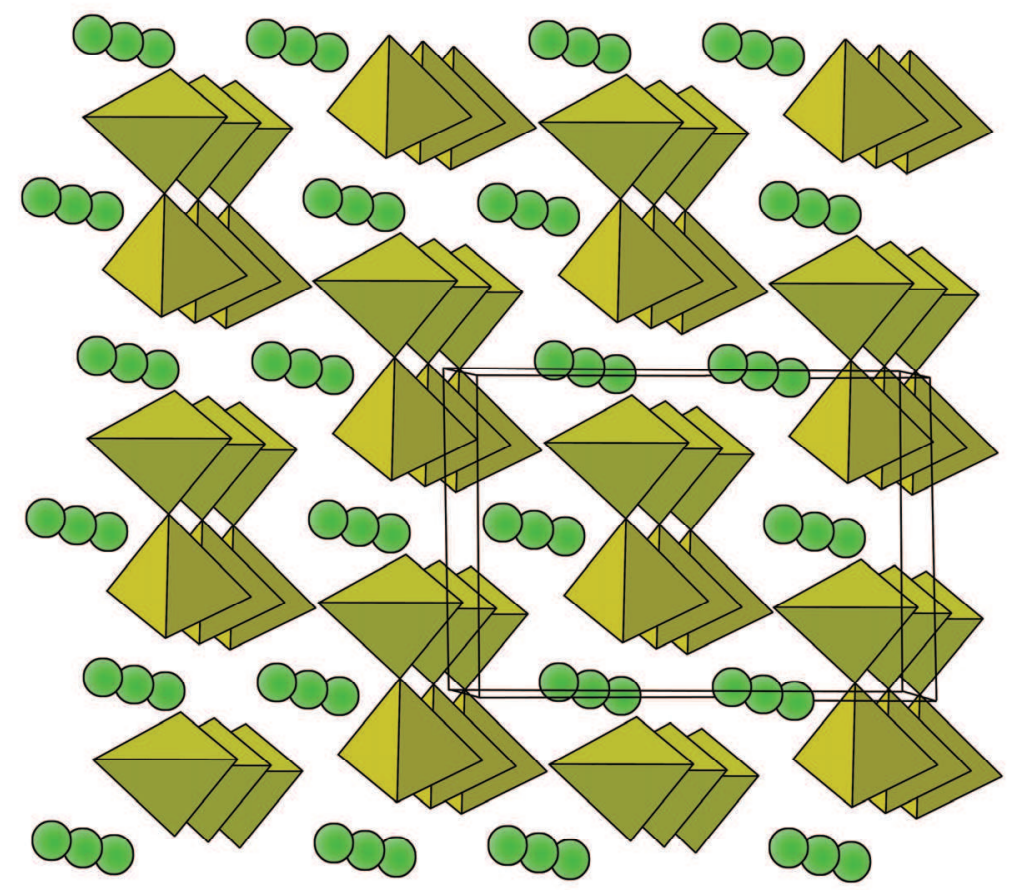

Fig. 2. Schematic diagram for the monoclinic structure of $\mathrm{Lu}_{2} \mathrm{Si}_{2} \mathrm{O}_{7}$ crystal $\mathrm{Lu}$ ions are green and $\left[\mathrm{Si}_{2} \mathrm{O}_{7}\right]$ groups are yellow. Reprinted from (Yan et al., 2006).

\section{Experimental}

\subsection{Preparation of pyrosilicate powder phosphor}

$\mathrm{Y}\left(\mathrm{NO}_{3}\right)_{3} \cdot 6 \mathrm{H}_{2} \mathrm{O}$ (in the case of YPS) or $\mathrm{Lu}\left(\mathrm{NO}_{3}\right)_{3} \cdot 5 \mathrm{H}_{2} \mathrm{O}$ (99.9\%, Sigma-Aldrich), TEOS (98\%,Sigma-Aldrich), 96\% methanol and $\mathrm{HNO}_{3}(0.03 \mathrm{M})$ were used as starting materials. First, $\mathrm{RE}\left(\mathrm{NO}_{3}\right)_{3} n \mathrm{H}_{2} \mathrm{O}(\mathrm{RE}=\mathrm{Y}, \mathrm{Lu})$ was dissolved in methanol $\left(\mathrm{CH}_{3} \mathrm{OH}\right)$ at $\mathrm{RT}$ and $\mathrm{HNO}_{3}$ was added as catalyser for TEOS acid hydrolysis and condensation. Ce as doping element in the form of nitrate was then dissolved in methanol solution and the molar ratio Ce:RE was fixed onto the value of 1:199 (0,5 molar \% of Ce). After dissolving had been completed, TEOS was added at the molar ratio TEOS : $(\mathrm{RE}+\mathrm{Ce})$ fixed at the values 1:1. The gelation time at $55^{\circ} \mathrm{C}$ was approximately 24 hours. The samples were left 2 days for ageing. Then, they were progressively dried at $50^{\circ} \mathrm{C}$ for 3 days in flowing $\mathrm{N}_{2}$-atmosphere. After drying they were successively annealed at $900{ }^{\circ} \mathrm{C}$, at $1100{ }^{\circ} \mathrm{C}$ and $1300{ }^{\circ} \mathrm{C}$ with heating rate of $1{ }^{\circ} \mathrm{C} / \mathrm{min}$ under atmospheric pressure.

\subsection{Preparation of $\mathrm{YPS}: \mathrm{Ce} / \mathrm{SiO}_{2}$ a $\mathrm{LPS}: \mathrm{Ce} / \mathrm{SiO}_{2}$ nanocomposites}

The same starting materials were used for $\mathrm{YPS}(\mathrm{LPS}) \mathrm{Ce} / \mathrm{SiO}_{2}$ preparation like for pyrosilicate powder. The molar ratio of RE/Si was fixed onto 1/10. The final heating temperatures were chosen in the range of $1100-1300{ }^{\circ} \mathrm{C}$. The resulting samples were 
transparent with yellowish colour due to presence of Ce doping cations. When the silica matrix had crystallized, samples became milky and non-transparent.

\subsection{Characterization methods}

Powder XRD spectra were measured at ambient temperature using Phillips X-pert diffractometer with $\mathrm{Cu}$ Ka-radiation.

Thermal analysis (TG and DTA) measurements were carried out using SETARAM device and NETZSCH STA (QMS) 409/429-403 coupled to Mass Spectroscopy unit.

SEM was accomplished by Scanning Electron Microscope PHILIPS XL 30 CP and by Tescan Proxima SEM system equipped with SE, BSE and CL detectors.

Radio- and photoluminescence characterization was performed using model $5000 \mathrm{M}$ Spectrofluorometer, Horiba Jobin, Yvon equipped with single-grating monochromators and photon counting detectors. In case of radioluminescence and photoluminescence spectra the X-ray tube $(40 \mathrm{kV}, 15 \mathrm{~mA})$ Seifert $\mathrm{GmBh}$., and a $\mathrm{D}_{2}$ continuous lamp were used as the excitation sources, respectively. In case of photoluminescence decays the hydrogen-filled nanosecond and microsecond pulse xenon flashlamps were used for the fast and slow decay kinetics measurements, respectively. Scintillation decay was measured using the ps X-ray pulse source excitation and streak camera detection, see the details in (Yanagida et al., 2010). SpectraSolve software package (Ames Photonics) was used to apply deconvolution procedures to extract true decay times. All measurements were performed at RT.

\section{Results and discussion}

\subsection{Powder pyrosilicate materials}

\subsubsection{XRD measurements}

Powder YPS prepared by sol-gel methods was heat-treated at three different temperatures $\left(900,1100\right.$ and $\left.1300^{\circ} \mathrm{C}\right)$ and characterized using XRD.

The samples heated at $900^{\circ} \mathrm{C}$ were amorphous. Triclinic P-1 phase was formed at $1100^{\circ} \mathrm{C}$, while monoclinic $\mathrm{C} 2 / \mathrm{m}$ phase was obtained after heat-treatment at $1300^{\circ} \mathrm{C}$ (Fig. 3)

We observe simpler situation in case of lutetium silicates $\left(\mathrm{Lu}_{2} \mathrm{Si}_{2} \mathrm{O}_{7}\right)$ because LPS have only one stable phase at RT. The samples annealed at $1100{ }^{\circ} \mathrm{C}$ show $\mathrm{Lu}_{2} \mathrm{Si}_{2} \mathrm{O}_{7}$ pure phase pattern in agreement with PDF No. 35-0326, Fig. 4.

\subsubsection{Electron microscopy}

The TEM observations are consistent with the XRD results. Fig. 5 shows that the sample annealed at $900{ }^{\circ} \mathrm{C}$ has amorphous character, no regular crystalline shapes are observed.

The morphology of $1100{ }^{\circ} \mathrm{C}$ heat-treated samples (Fig. 6) is similar to the $900{ }^{\circ} \mathrm{C}$ heat-treated one. SEM image(left) show the particles of the size of few to several microns. Nevertheless, well developed crystals of the size of tens of nanometers are also observed (right part of the figure).

SEM and HR TEM of $1300{ }^{\circ} \mathrm{C}$ heat-treated YPS:Ce is shown at Fig. 7. The figure shows large crystallized particles of the size of microns. These particles no longer consist of submicron crystals (like in case of the $1100{ }^{\circ} \mathrm{C}$ heat-treated sample) but monolithic shape can be observed in TEM image (right side of Fig. 7).

The HRTEM observation of $\mathrm{Lu}_{2} \mathrm{Si}_{2} \mathrm{O}_{7}$ (Fig. 8a) heat-treated powder shows characteristic nonagglomerate particles of the size of about $20 \mathrm{~nm}$. At higher resolution (Fig. 8b), well ordered 
structure of LPS crystal can be seen. In Fig. 8c, the selected area electron diffraction (SAED) pattern is shown.

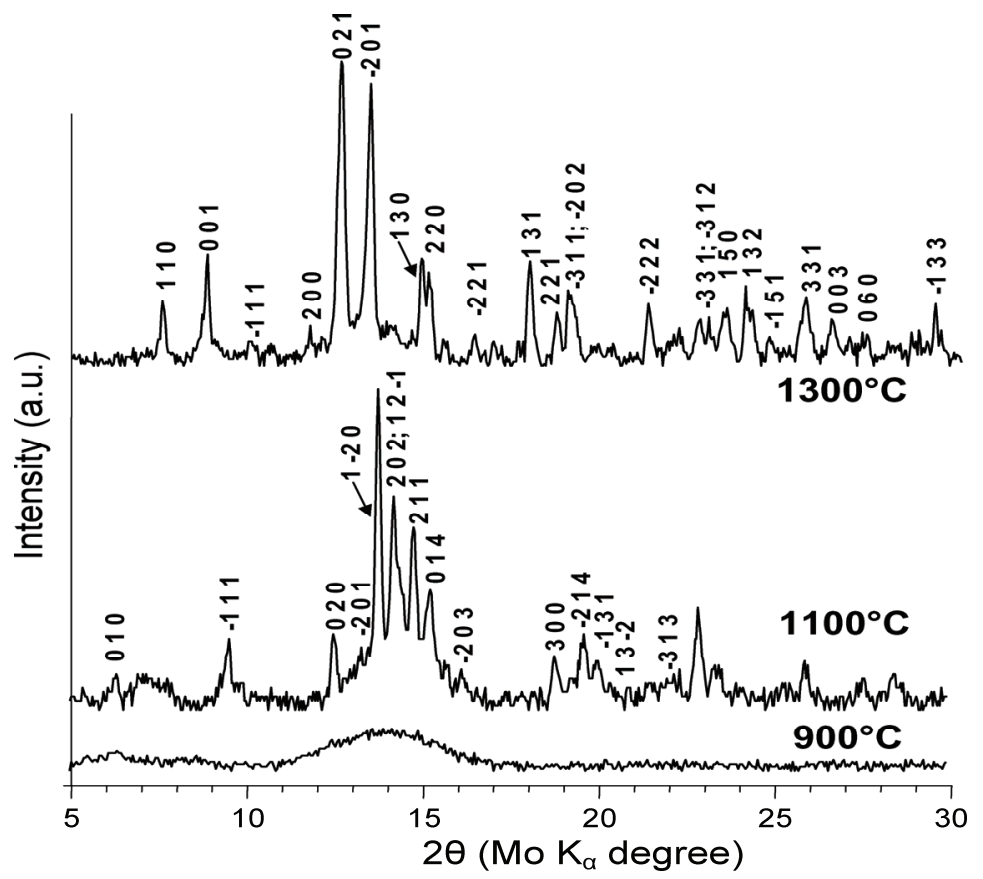

Fig. 3. X-ray diffraction pattern of the sample $\mathrm{Y}_{2} \mathrm{Si}_{2} \mathrm{O}_{7}$, annealed at 900,1100 and $1300{ }^{\circ} \mathrm{C}$.

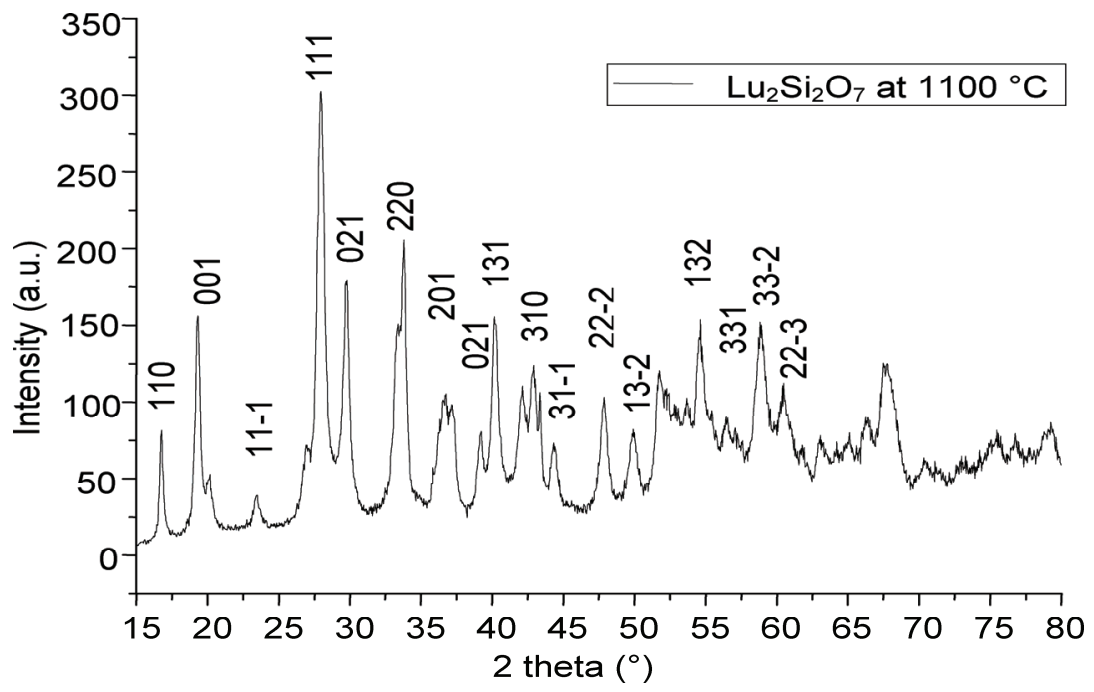

Fig. 4. X-ray diffraction pattern of the sample $\mathrm{Lu}_{2} \mathrm{Si}_{2} \mathrm{O}_{7}$, annealed at $1100{ }^{\circ} \mathrm{C}$ 


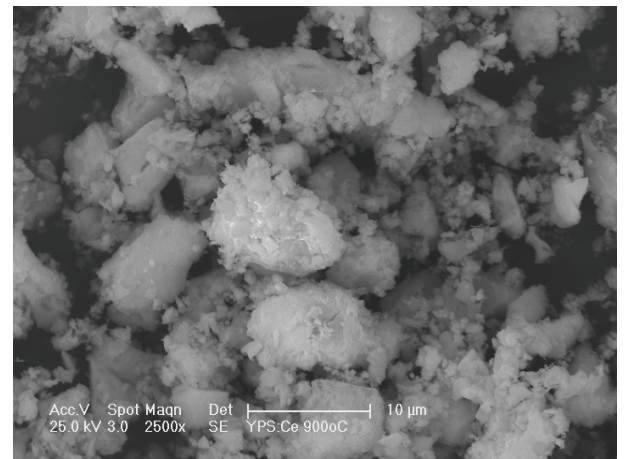

A

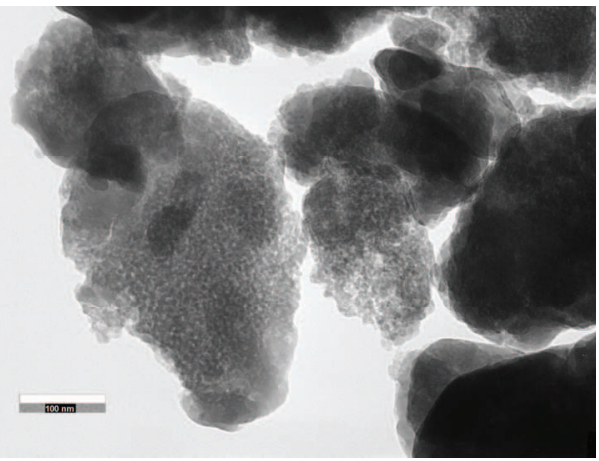

B

Fig. 5. SEM (A) and TEM (B) of YPS:Ce annealed at $900^{\circ} \mathrm{C}$.

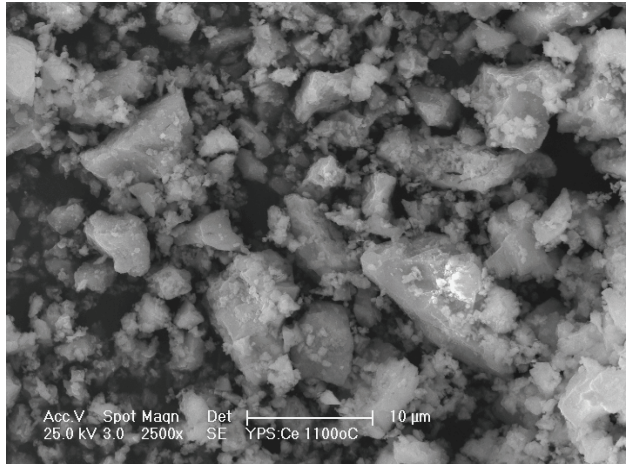

A

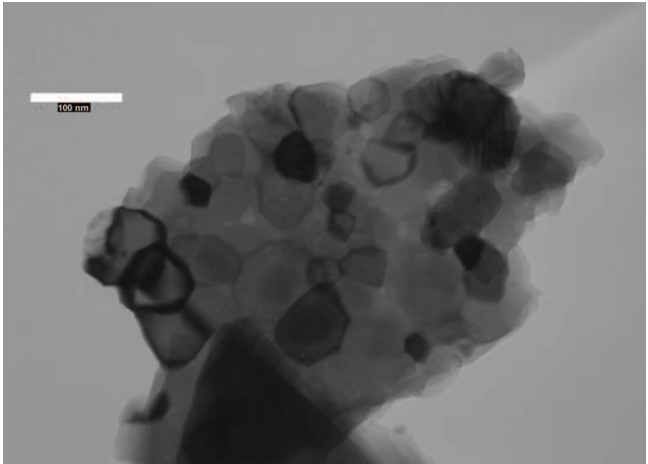

B

Fig. 6. SEM (A) and TEM (B) of YPS annealed at $1100{ }^{\circ} \mathrm{C}$ heat treated sample. Left image (SEM) shows the glassy aspect of sample while right image (TEM) shows the formation of nanometres-sized crystals.

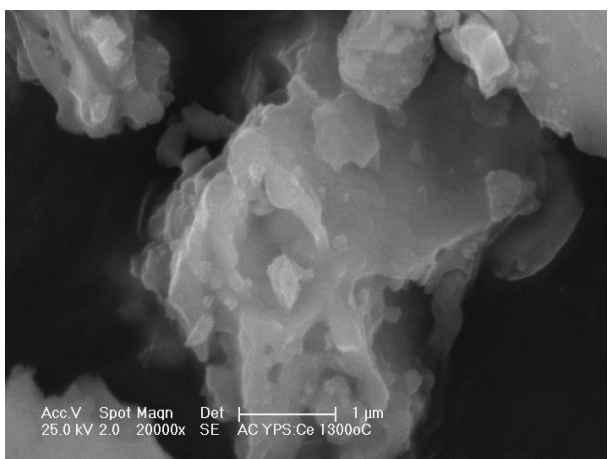

A

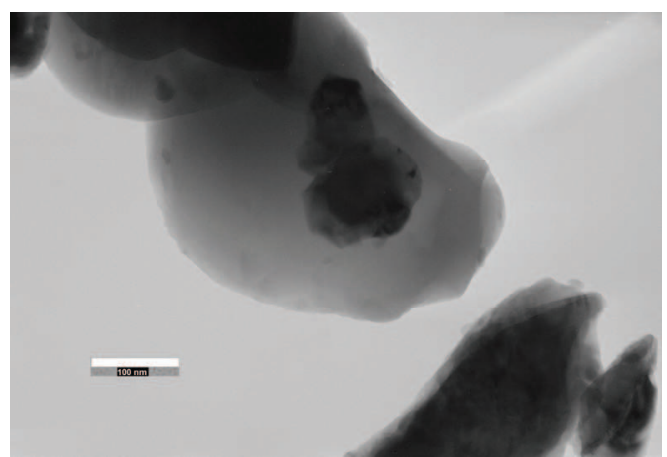

B

Fig. 7. SEM (A) and TEM (B) of $1300^{\circ} \mathrm{C}$ heat treated YPS:Ce 


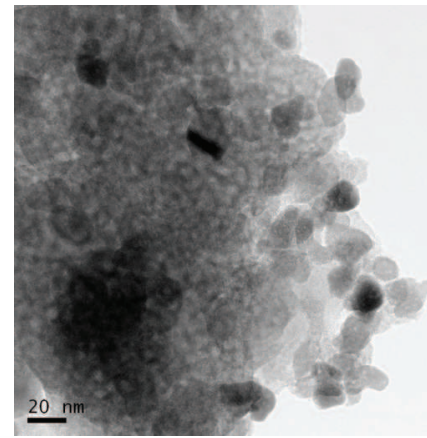

A

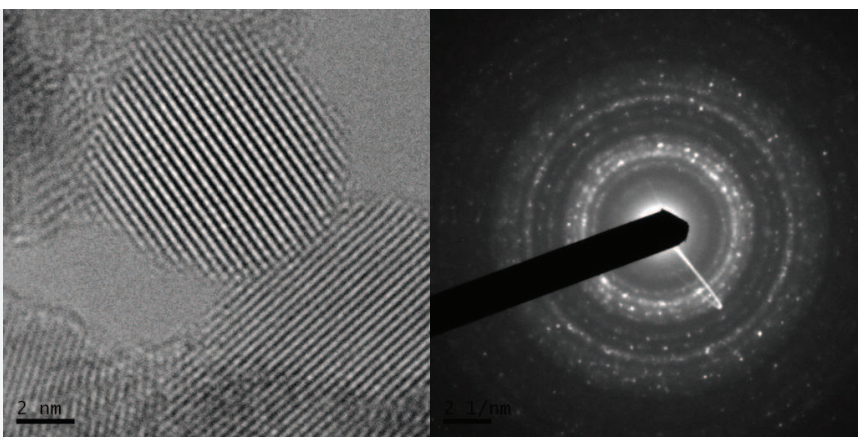

B

C

Fig. 8. $(a, b, c)$ HRTEM measurement of $\mathrm{Lu}_{2} \mathrm{Si}_{2} \mathrm{O}_{7}$

\subsubsection{Luminescent properties}

Radioluminescence spectra of the YPS:Ce samples were measured under X-ray excitation. The spectra are dominated by the $\mathrm{Ce}^{3+} 5 \mathrm{~d}_{1}-4 \mathrm{f}$ emission peaks at about $440 \mathrm{~nm}$, Fig. 9 The intensity increased strongly with increasing temperature of the heat treatment. The maximum of the spectrum is noticeably long-wavelength shifted with respect to that of YPS:Ce single crystals $(361+381 \mathrm{~nm}$ ) (Feng et al., 2010). It points to a number of perturbation/defect-associated Ce sites in the YPS:Ce powder because such perturbations are known to shift $\mathrm{Ce}^{3+}$ emission to lower energy (Pedrini et al., 1992). In YPS:Ce with increasing annealing temperature the maximum of the spectrum shifts to shorter wavelength with approximately constant width (Fig. 10). Such intensity and shape evolution of the spectra can be caused by structural evolution with heat treatment temperature described before.

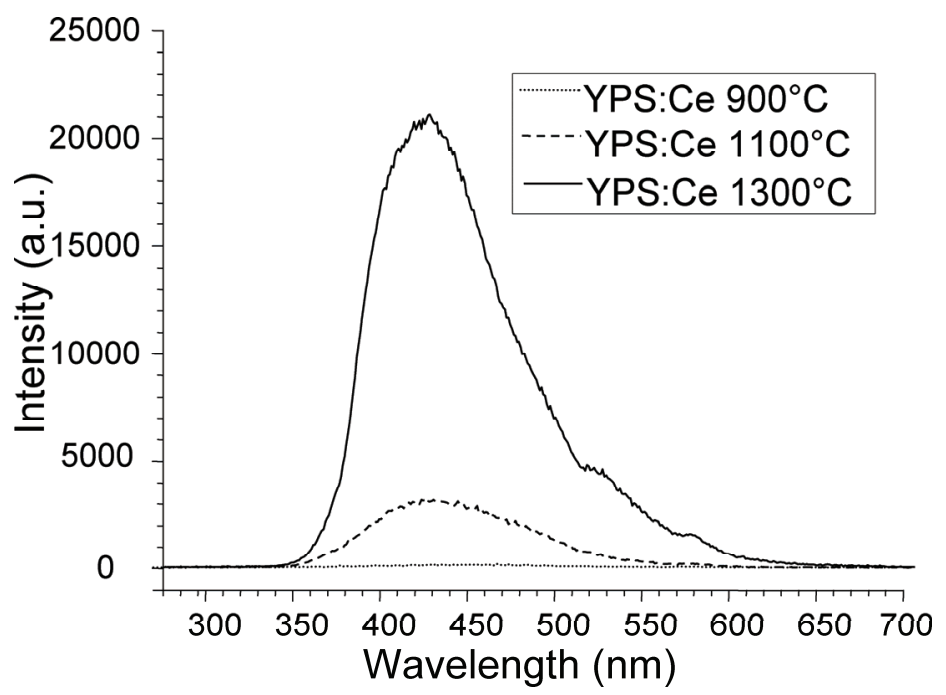

Fig. 9. Radioluminescence spectra dependence on the heat treatment temperature of the Cedoped YPS (excitation by an X-ray tube, $40 \mathrm{kV}$ ) Spectra can be mutually compared in an absolute scale. Small dips around $510 \mathrm{~nm}$ and $565 \mathrm{~nm}$ are experimental artifacts 


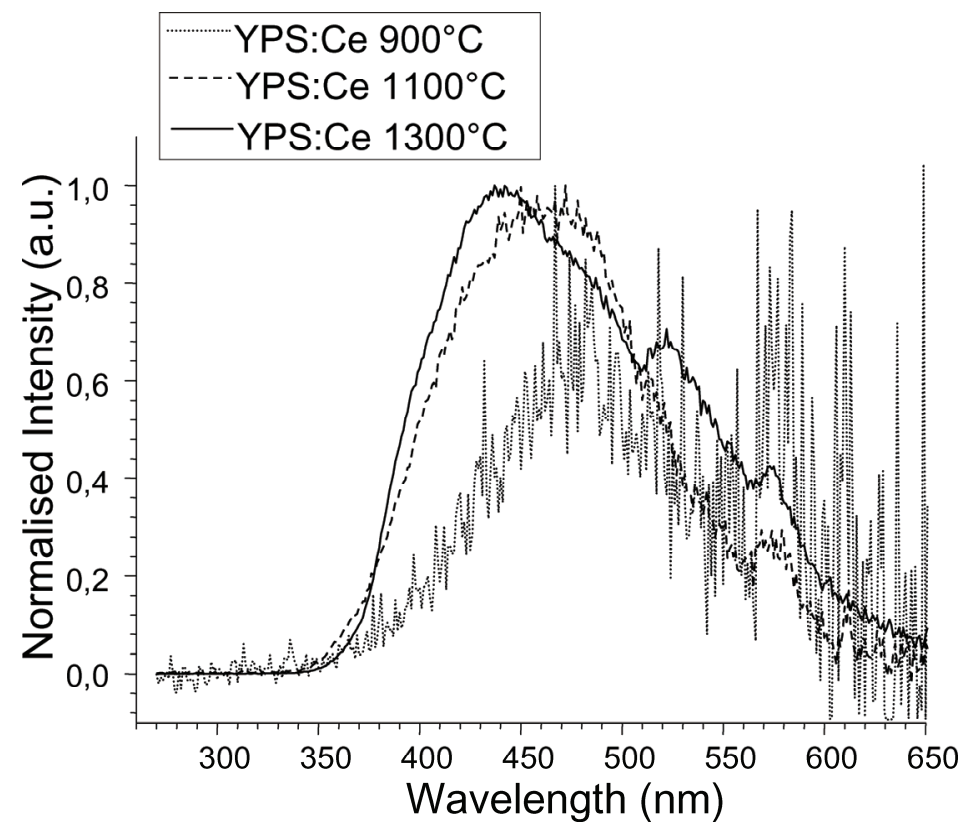

Fig. 10. Normalized radioluminescence spectra of YPS:Ce and their dependence on annealing temperature. Small dips around $510 \mathrm{~nm}$ and $565 \mathrm{~nm}$ are experimental artifacts.

Photoluminescence decays in Fig. 11 were measured for all the YPS:Ce samples. The decays are normalized for better comparison of the differences.

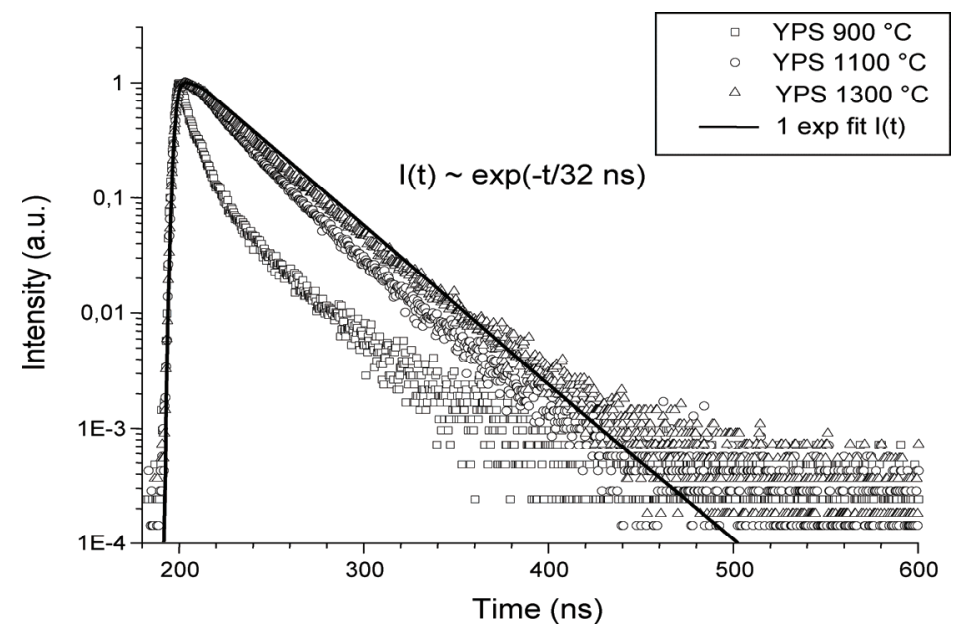

Fig. 11. Normalized photoluminescence decays of YPS:Ce heat-treated at different temperatures marked in the legend. Single exponential fit with decay time of $32 \mathrm{~ns}$ by a solid line is shown for $1300{ }^{\circ} \mathrm{C}$ treated samples to evaluate the decay time. exc $=345 \mathrm{~nm}$, em $=440$ nm. 
There is a clear correlation between the decay shape and heat treatment temperature: in the sample treated at $1300{ }^{\circ} \mathrm{C}$, the decay is close to a single exponential with the decay time of about 32 ns. The decay becomes faster and strongly deviated from a single exponential at lower heat treatment temperatures. The distortion of single exponential decay points to a nonradiative energy transfer (quenching) process which occurs from the $\mathrm{Ce}^{3+}$ relaxed $5 \mathrm{~d}_{1}$ excited state towards a nearby lying defect level. The relative photoluminescence efficiency losses caused by this process were estimated from the integral of normalized decay curves. In the YPS host the $\mathrm{Ce}^{3+}$ photoluminescence quantum efficiency is diminished to 0.87 and 0.35 for $1100{ }^{\circ} \mathrm{C}$ and $900{ }^{\circ} \mathrm{C}$ heat-treated samples, respectively, relative to the $1300{ }^{\circ} \mathrm{C}$ heattreated sample. In the $1300{ }^{\circ} \mathrm{C}$ heat-treated sample the non-decreasing temperature dependence of the $\mathrm{Ce}^{3+}$ decay time from $80 \mathrm{~K}$ up to the temperature well above RT (not shown here) evidences that the quantum efficiency of $\mathrm{Ce}^{3+}$ at $\mathrm{RT}$ is close to unity. The calculated photoluminescence efficiency losses related to the $\mathrm{Ce}^{3+}$ centre itself are much less significant with respect to the decrease of scintillation efficiency reflected in the radioluminescence intensity dependence on annealing temperature in Fig. 9. This means that the loss of scintillation efficiency in the samples heat-treated at lower temperatures occurs mainly in the transport stage, i.e. in the host material itself before reaching the $\mathrm{Ce}^{3+}$ luminescence centres.

In Fig. 12 the spectra are provided for the Ce-doped LPS. They correspond well with the earlier published data on LPS:Ce single crystals (Pidol et al., 2007; Feng et al., 2010), including Stokes shift value of $0.27 \mathrm{eV}$.

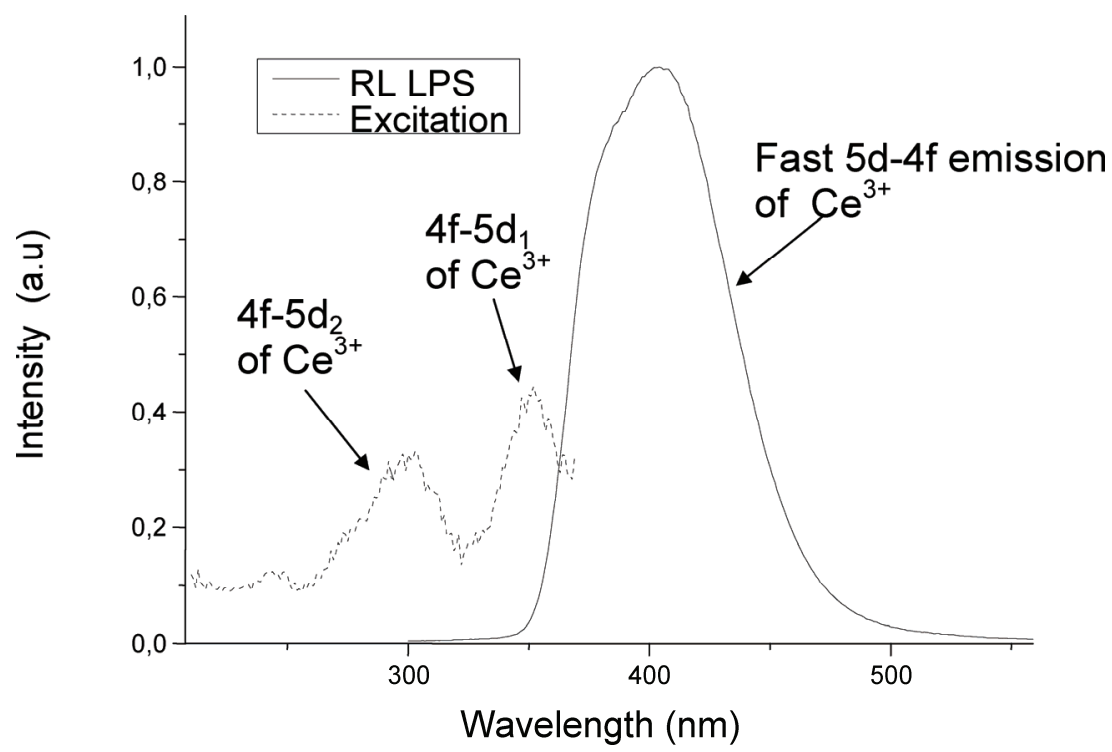

Fig. 12. Normalized PL excitation (em=420 nm) and RL (X-ray, $40 \mathrm{kV})$ spectra of Ce-doped LPS annealed at $1100^{\circ} \mathrm{C}$.

PL decay shows nanosecond decay time of 34 ns (Fig. 13), which is due to the allowed $5 \mathrm{~d}-4 \mathrm{f}$ transition of $\mathrm{Ce}^{3+}$ and that is in very good agreement with that measured in LPS:Ce single crystals (Pidol et al., 2007; Feng et al., 2010). Decay acceleration in the initial part of the 
decay curve might be due to an energy transfer from $\mathrm{Ce}^{3+}$ centres to some defects e.g. at grain surface layer.

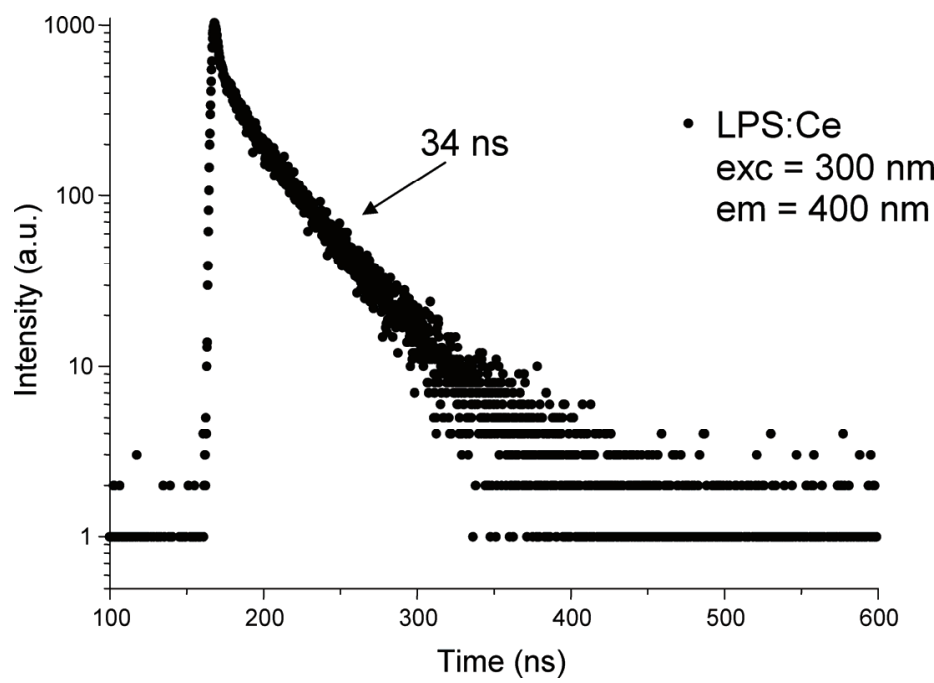

Fig. 13. Photoluminescence decays of the Ce-doped LPS (exc $=300 \mathrm{~nm}$, em $=400 \mathrm{~nm}$ ) annealed at $1100{ }^{\circ} \mathrm{C}$. Decay time of 34 ns was evaluated in the tail of the decay.

\subsection{Nanocomposite materials}

The $\mathrm{SiO}_{2} / \mathrm{RE}_{2} \mathrm{Si}_{2} \mathrm{O}_{7}: \mathrm{Ce}(\mathrm{RE}=\mathrm{Y}, \mathrm{Lu})$ nanocomposite samples were prepared using the same sol-gel method. The overstoichiometric ratio of $\mathrm{RE} / \mathrm{Si}(1 / 10)$ was used for the material preparation.

The nanocomposites are transparent when silica matrix is amorphous, see Fig. 14, but during the heat treatment at the temperature of more than $1250{ }^{\circ} \mathrm{C}$ the crystallisation of amorphous silica matrix takes place and cristobalite structure is formed. Consequently, the sample breaks into small pieces of sub-millimetre size.

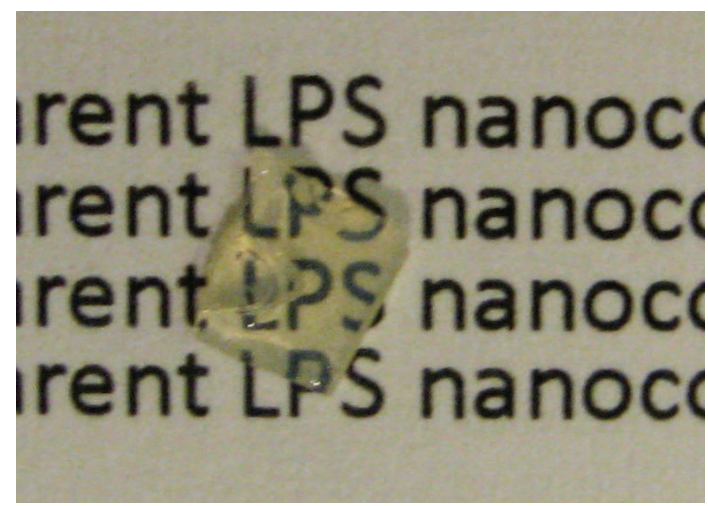

Fig. 14. Photo of the transparent $\mathrm{SiO}_{2} / \mathrm{Lu}_{2} \mathrm{Si}_{2} \mathrm{O}_{7}: \mathrm{Ce}$ nanocomposite heat-treated at $1000{ }^{\circ} \mathrm{C}$. 


\subsubsection{XRD measurements}

$\mathrm{SiO}_{2} / \mathrm{Y}_{2} \mathrm{Si}_{2} \mathrm{O}_{7}$ system was prepared and heat-treated at different temperatures. The samples annealed at $1000^{\circ} \mathrm{C}$ are amorphous and transparent. Further increase of annealing temperature to $1100-1200{ }^{\circ} \mathrm{C}$ leads to crystallisation of both silica matrix (into crystobalite) and of $\mathrm{Y}_{2} \mathrm{Si}_{2} \mathrm{O}_{7}$ as shown in Fig. 15. Fig. 16 shows XRD spectra of the samples denoted as TK10 which are transparent. Annealing for $2 \mathrm{~h}$ at $1000^{\circ} \mathrm{C}$ and $1100^{\circ} \mathrm{C}$ was carried out on the TK10 samples first and then a rapid thermal treatment (RTT) procedure was applied at $1250^{\circ} \mathrm{C}$ and $1300^{\circ} \mathrm{C}$, consisting of increase of temperature from $1000^{\circ} \mathrm{C}$ or $1100{ }^{\circ} \mathrm{C}$ to $1250^{\circ} \mathrm{C}$ $1300^{\circ} \mathrm{C}$ in 2 minutes, 5 minutes at this temperature, cooling down in 5 minutes. The RTT temperature of $1300^{\circ} \mathrm{C}$ keeps sample transparent and amorphous but luminescent intensity improves. It is interesting to note that in case of non-transparent crystallized sample $\alpha$-YPS phase is observed in XRD spectra, while in transparent ones rather $\beta$-YPS phase is found or sample remains purely amorphous.

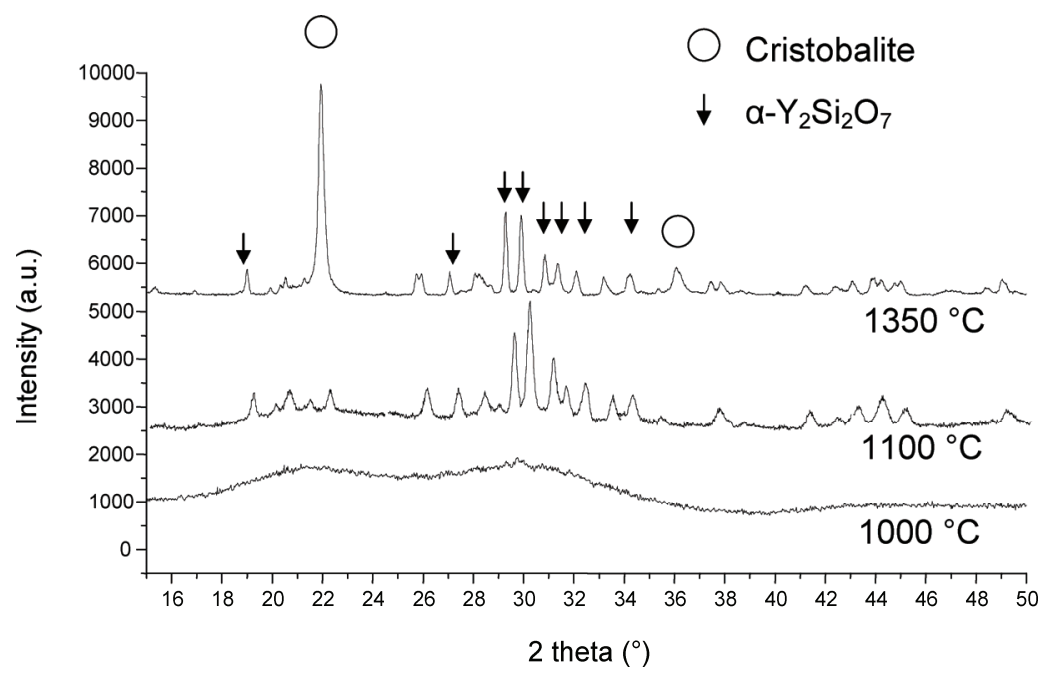

Fig. 15. XRD patterns of $\mathrm{SiO}_{2} / \mathrm{Y}_{2} \mathrm{Si}_{2} \mathrm{O}_{7}:$ Ce nanocomposites (denoted as A10) heat-treated at different temperatures.

The same XRD study was carried out for the lutetium analogs, see Fig. 17. The samples were progressively heat-treated at the temperatures from $1100^{\circ} \mathrm{C}$ to $1300^{\circ} \mathrm{C}$ (by $50^{\circ} \mathrm{C}$, for 2 hours at a given temperature) and their XRD spectra were measured. The samples heat-treated up to $1200{ }^{\circ} \mathrm{C}$ are mainly amorphous. Complete crystallization occurs at $1300{ }^{\circ} \mathrm{C}$, the XRD pattern of this sample consist of $\mathrm{Lu}_{2} \mathrm{Si}_{2} \mathrm{O}_{7}$ and $\mathrm{SiO}_{2}$ (cristobalite).

\subsubsection{Electron microscopy}

In Fig. 18 the SEM and HR TEM images of $\mathrm{SiO}_{2} / \mathrm{Y}_{2} \mathrm{Si}_{2} \mathrm{O}_{7}$ nanocomposites (Sample TK10 heat-treated at $1000^{\circ} \mathrm{C}$ and $1100{ }^{\circ} \mathrm{C}$ ) are shown.

SEM image with the lower resolution (Fig. 18a) shows the homogeneous glassy aspect of the sample. HRTEM images reveal the internal structure of this sample (Fig. 18b,c). Regular round $\mathrm{Y}_{2} \mathrm{Si}_{2} \mathrm{O}_{7}$ particles of tens of nanometers size embedded in the silica matrix are clearly observed. The ideal round shape can be surprising because the crystals do not crystallize in 


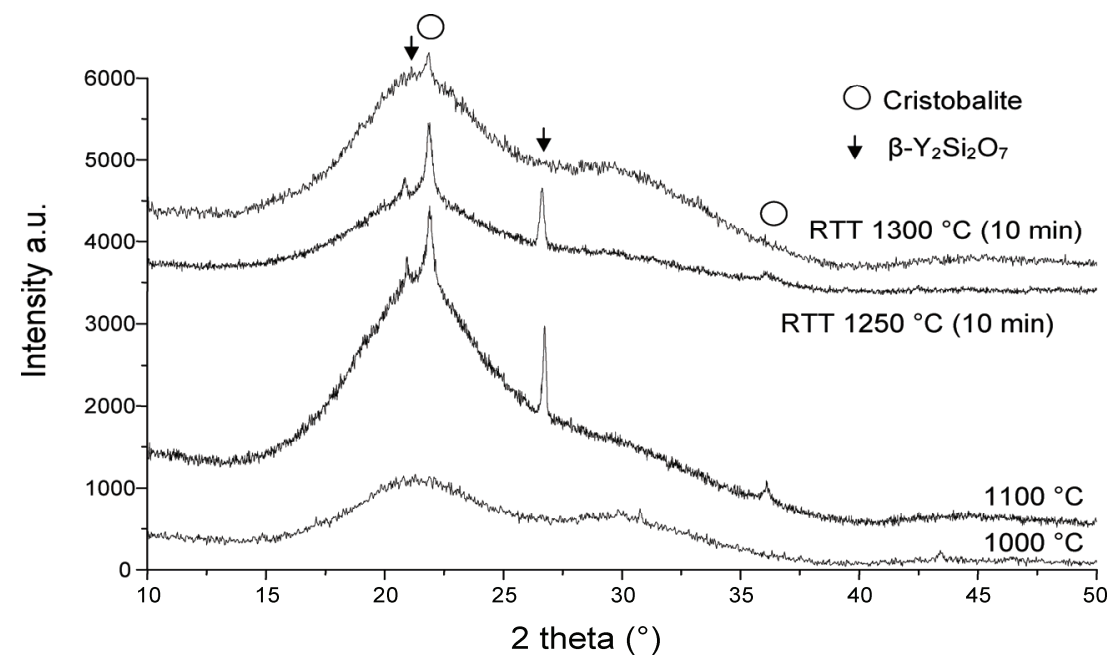

Fig. 16. TK samples annealed at $1000^{\circ} \mathrm{C}, 1100$ for 2 hours, RTT procedure then applied at $1250{ }^{\circ} \mathrm{C}$ and $1300^{\circ} \mathrm{C}$ as described in the text before.

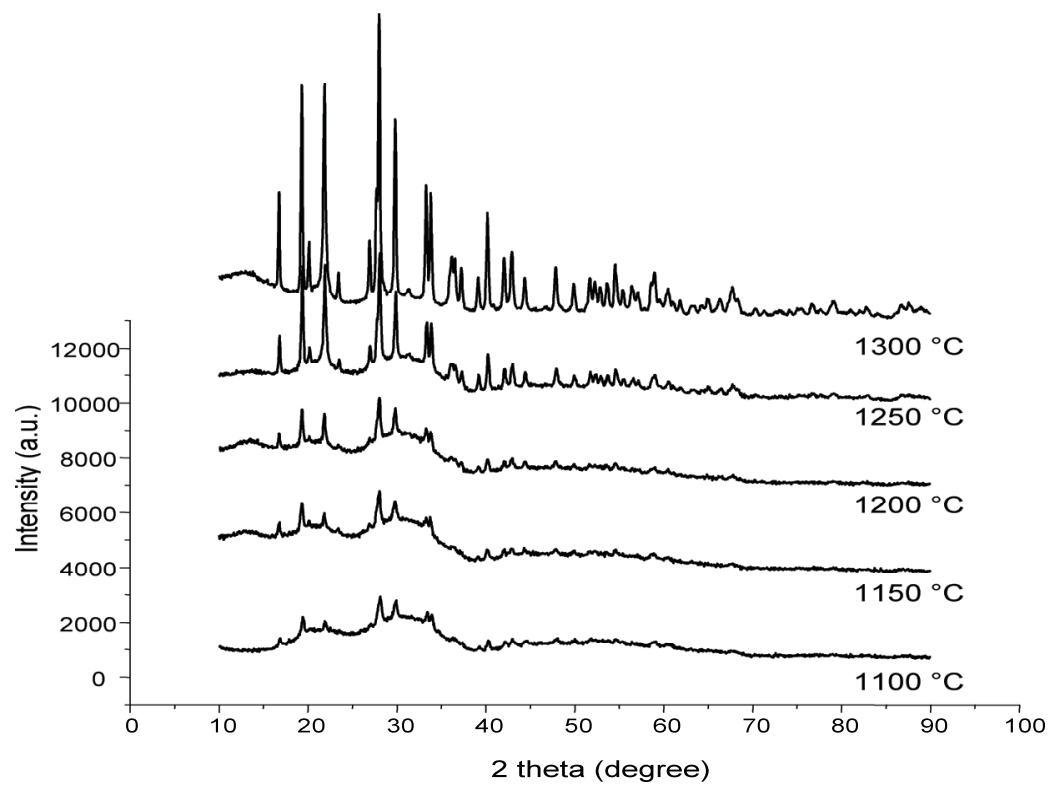

Fig. 17. XRD spectra of $\mathrm{SiO}_{2} / \mathrm{Lu}_{2} \mathrm{Si}_{2} \mathrm{O}_{7}$ composite after annealing at different, gradually increasing temperatures. 


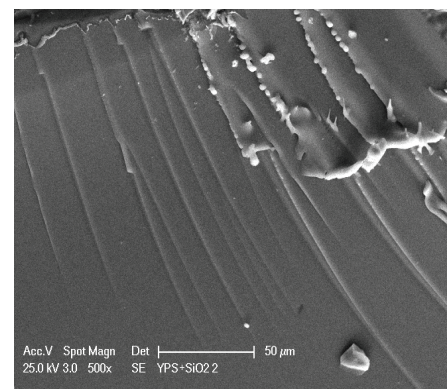

a)

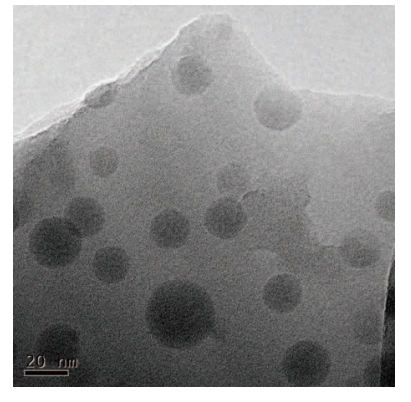

b)

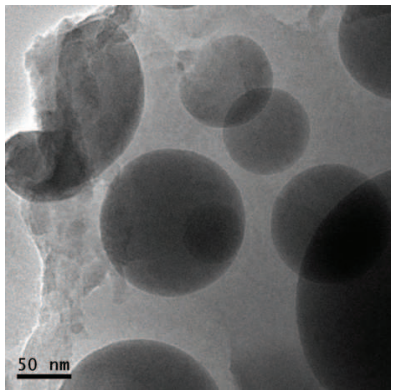

c)

Fig. 18. SEM and HR TEM images of $\mathrm{TK} 10 \mathrm{SiO}_{2} / \mathrm{Y}_{2} \mathrm{Si}_{2} \mathrm{O}_{7}$ nanocomposite samples: a) corresponds to SEM of natural sample surface, annealed at $1000^{\circ} \mathrm{C}, \mathrm{b}$ ) HRTEM of sample annealed at $1000^{\circ} \mathrm{C}$, c) HR TEM of sample annealed at $1100^{\circ} \mathrm{C}$.

the shapes of spherical symmetry. The explanation is found in the $\mathrm{Y}_{2} \mathrm{O}_{3}$ phase diagram (Fig. 1). $\mathrm{Y}_{2} \mathrm{Si}_{2} \mathrm{O}_{7}$ and $\mathrm{SiO}_{2}$ are not miscible even in the liquid state. The surplus of $\mathrm{SiO}_{2}$ leads to the phase separation of $\mathrm{Y}_{2} \mathrm{Si}_{2} \mathrm{O}_{7}$ which forms spherical particles in order to minimize the surface energy (like the oil droplets in the water). The resulting nanocomposite is transparent if the particle size of these nanoparticles is smaller than $1 / 10$ of the wavelength of the used light, i.e. below 40-50 $\mathrm{nm}$ (Krell et al., 2009).

The nanocomposite $\mathrm{Lu}_{2} \mathrm{Si}_{2} \mathrm{O}_{7} / \mathrm{SiO} 2$ has the same tendency. The HRTEM images in Fig. 19 show the mean particle size increasing with the heat treatment temperature. Statistical evaluation of the particle size distribution from HRTEM image was performed and is shown in Fig. 20 for the sample heat-treated at $1100^{\circ} \mathrm{C}$.

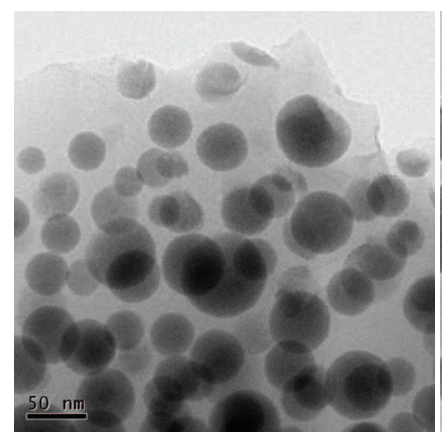

a)

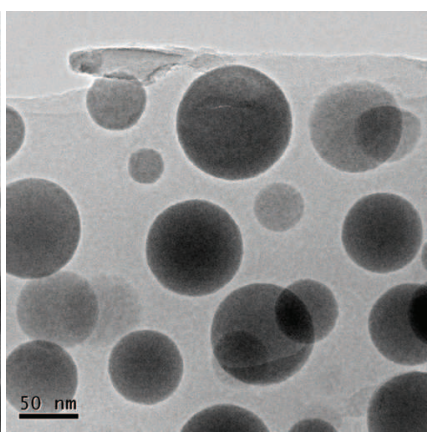

b)

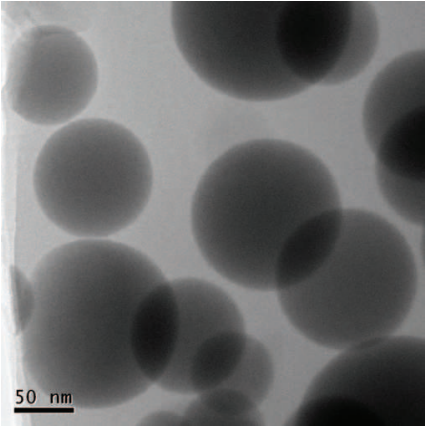

c)

Fig. 19. HRTEM of $\mathrm{SiO}_{2} / \mathrm{Lu}_{2} \mathrm{Si}_{2} \mathrm{O}_{7}$ nanocomposite heat-treated at $1100{ }^{\circ} \mathrm{C}(\mathrm{a}), 1200{ }^{\circ} \mathrm{C}(\mathrm{b})$ and $1300{ }^{\circ} \mathrm{C}(\mathrm{c})$.

The average particle size of the $1100{ }^{\circ} \mathrm{C}$ heat-treated sample is about $30 \mathrm{~nm}$, the $1200{ }^{\circ} \mathrm{C}$ heat-treated sample reaches the mean particle size of about $50 \mathrm{~nm}$ and the $1300{ }^{\circ} \mathrm{C}$ heattreated nanocomposite shows the particle size of about $100 \mathrm{~nm}$. 


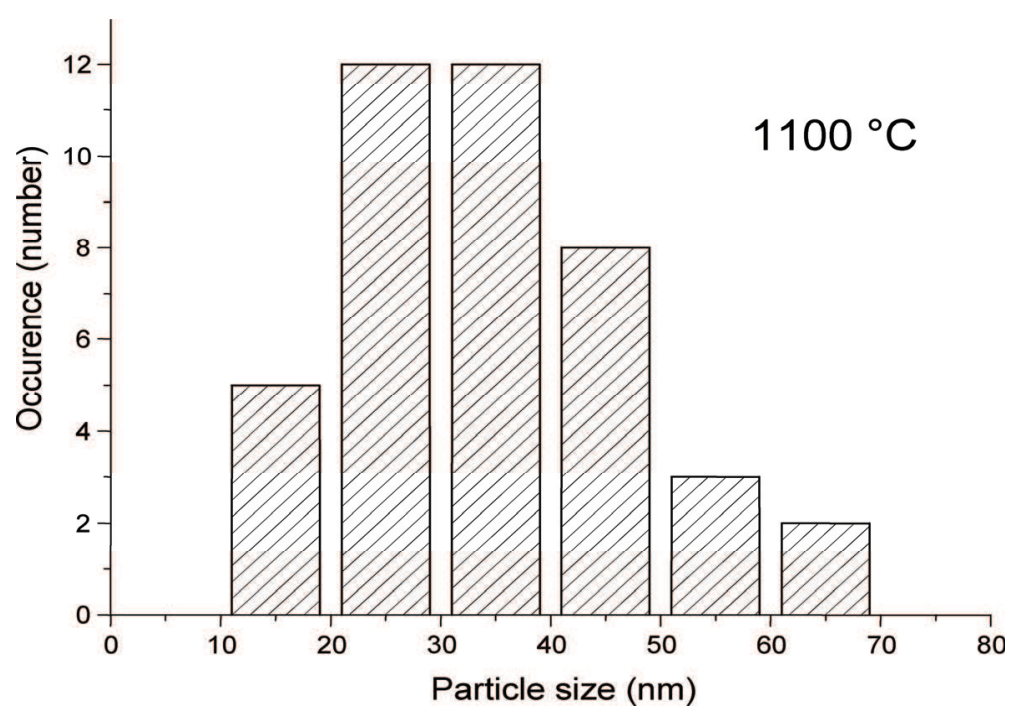

Fig. 20. Size distribution of LPS nanospheres for the sample heat-treated at $1100{ }^{\circ} \mathrm{C}$ evaluated from HRTEM images.

\subsubsection{Thermal analysis}

Thermal behaviour of the both Yttrium and lutetium nanocomposites was similar. Fig. 21 shows the TG and DTA analysis of $\mathrm{SiO}_{2} / \mathrm{Lu}_{2} \mathrm{Si}_{2} \mathrm{O}_{7}$ nanocomposite. First decrease of TG within the range of $200^{\circ} \mathrm{C}$ to $400^{\circ} \mathrm{C}$ corresponds to the elimination of organic species in the matrix and decomposition of the lutetium nitrate. The mass of $\mathrm{SiO}_{2} / \mathrm{Lu}_{2} \mathrm{Si}_{2} \mathrm{O}_{7}$ nanocomposite is constant above $800^{\circ} \mathrm{C}$. DTA curve shows exo-effect at $300^{\circ} \mathrm{C}$ which corresponds to the oxidation of organic residue by nitrates. Second exo-effect situated near $1100^{\circ} \mathrm{C}$ probably corresponds to the crystallisation of both amorphous silica matrix and $\mathrm{Lu}_{2} \mathrm{Si}_{2} \mathrm{O}_{7}$ as could be seen from XRD spectra. The crystallisation of both components took place simultaneously, therefore it was not possible to distinguish on process from the other. Moreover, the temperature of this transition varied significantly within the range of 1100 to $1250^{\circ} \mathrm{C}$ when some of the parameters (heating rate, air or inert atmosphere, different sample size) were changed in DTA measurement. It means that this crystallisation is kinetically very slow process, possibly hindered in big parts of the composite. This fact could be used for the RTT procedure when the crystallization of nanoparticles of $\mathrm{Lu}_{2} \mathrm{Si}_{2} \mathrm{O}_{7}$ can be expected while silica matrix remains amorphous.

\subsubsection{Luminescent properties}

RL spectra of the bulk composite TK 10 YPS:Ce $/ \mathrm{SiO}_{2}$ sample are shown in Fig. 22. Emission intensity of yet amorphous sample heat-treated at $1100{ }^{\circ} \mathrm{C}$ is smaller and its maximum is low energy shifted $(455 \mathrm{~nm})$ in comparison with the densely cracked one which was heattreated at $1300{ }^{\circ} \mathrm{C}$. The latter spectrum shows the subbands at about $360 \mathrm{~nm}$ and $382 \mathrm{~nm}$ which are very close to those in YPS:Ce single crystal (Feng et al., 2010). It can be interpreted that the $\mathrm{Ce}^{3+}$ centres are well embedded in regular YPS structure. Furthermore, comparison with standard BGO scintillator shows reasonable scintillation efficiency of the 
nanocomposite YPS:Ce/ $\mathrm{SiO}_{2}$ system heat-treated at $1300{ }^{\circ} \mathrm{C}$. In case of samples which were prepared in powder form from the very beginning the RL intensity shows even higher values compared to BGO, Fig. 23

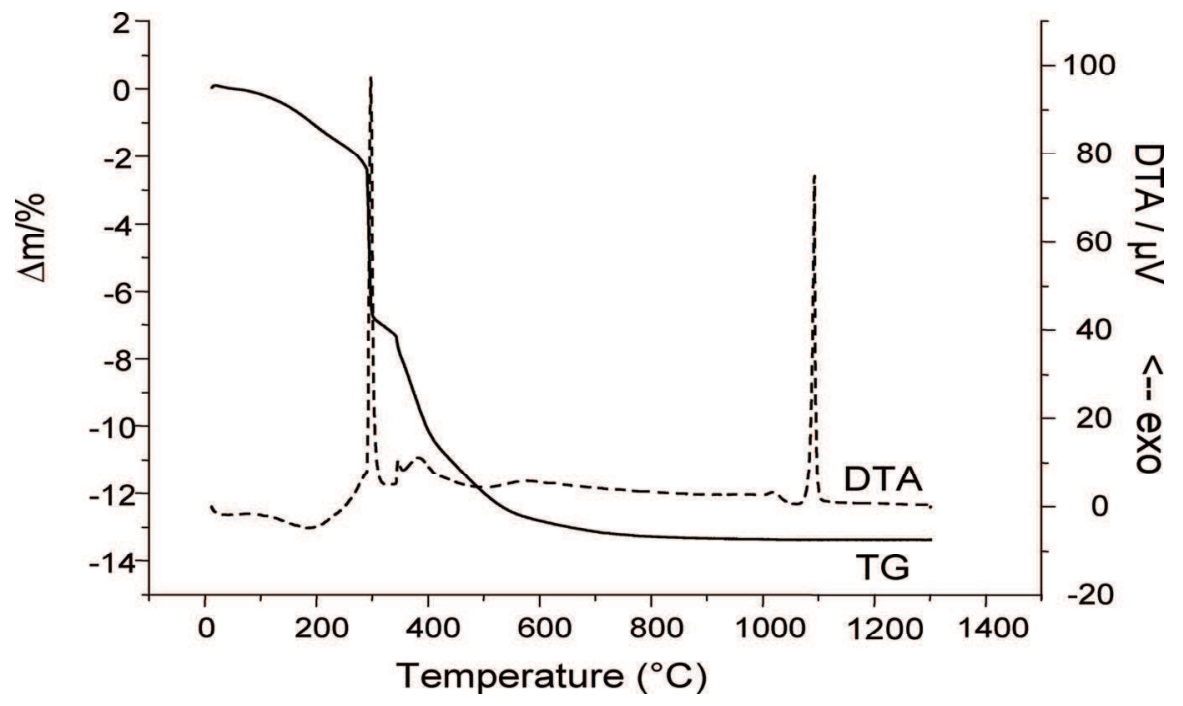

Fig. 21. TG and DTA analysis of $\mathrm{SiO}_{2} /$ LPS nanocomposite

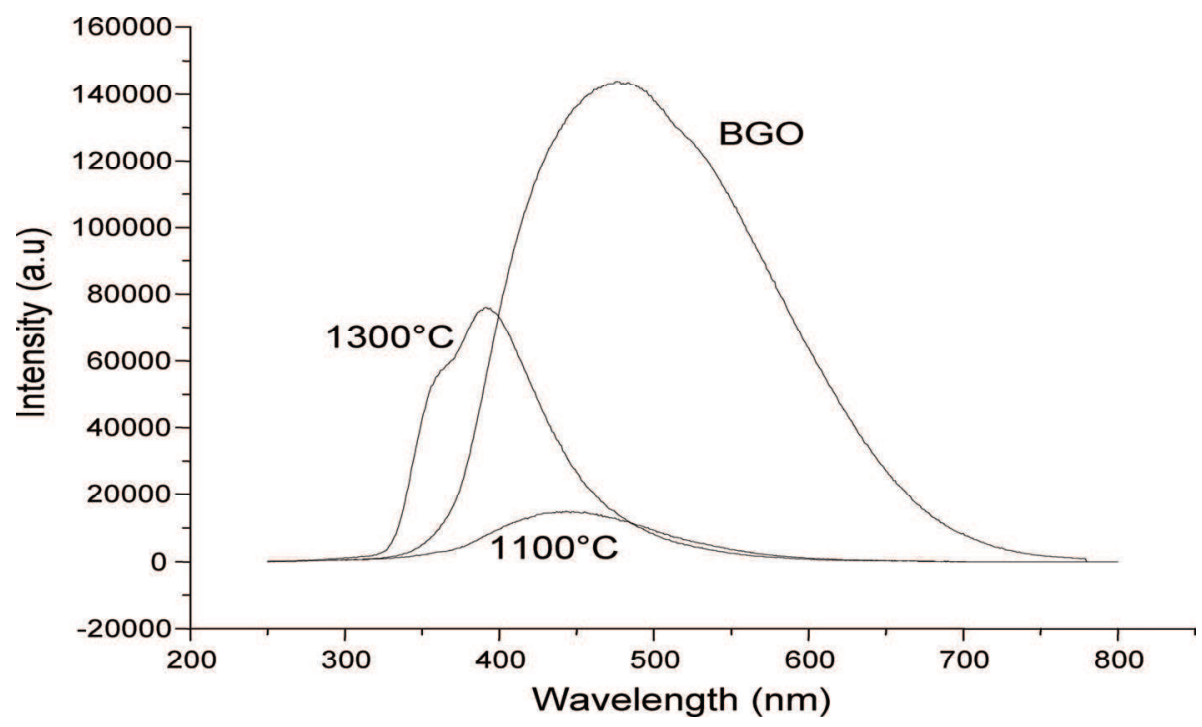

Fig. 22. RL spectra of the bulk TK 10 YPS:Ce/ $\mathrm{SiO}_{2}$ nanocomposite sample heat-treated at $1100^{\circ} \mathrm{C}$ and $1300{ }^{\circ} \mathrm{C}$ and the spectrum of BGO standard scintillator sample. 


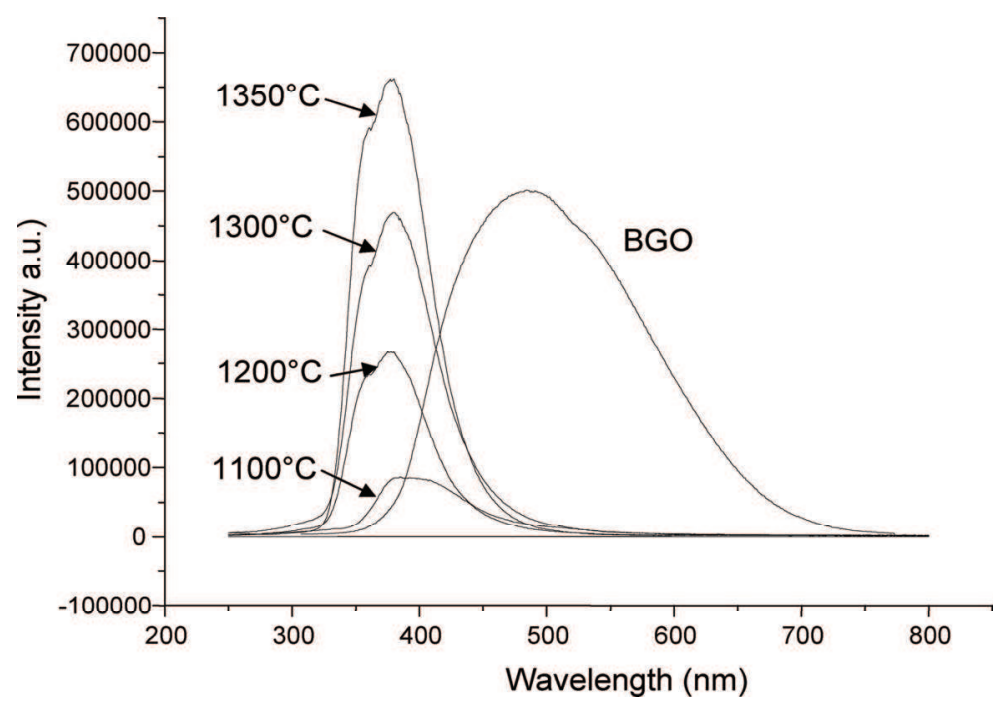

Fig. 23. RL spectra of A10 nanocomposite YPS:Ce/ $\mathrm{SiO}_{2}$ samples prepared in powder form. Annealing temperatures are shown in the figure, comparison with BGO standard scintillator sample is provided as well.

Fig. 24 shows the PL and PLE spectra of A10 powder nanocomposite sample. Very good correspondence of both emission and excitation subbands is found compared to the bands reported for YPS:Ce single crystal (Feng et al., 2010) which again points to embedding $\mathrm{Ce}^{3+}$ ions in well ordered YPS structure without excessive influence of any lattice flaws and perturbations.

Luminescence characteristics of LPS:Ce/ $\mathrm{SiO}_{2}$ nanocomposite samples were found to be quite analogous to those of yttrium-based system ones. RL intensity strongly increases with annealing temperature and comparatively higher intensities are obtained in comparison to the YPS:Ce/ $\mathrm{SiO}_{2}$ ones, see Fig. 25. Normalized spectra show high energy shift and smaller FWHM with increasing annealing temperature, see Fig. 26. Position of excitation and emission peaks for $\mathrm{T}_{\mathrm{an}}=1250-1300{ }^{\circ} \mathrm{C}$ match reasonably well those of LPS:Ce single crystal (Pidol et al., 2007; Feng et al., 2010). RL spectrum for the highest annealing temperatures can be in fact perfectly decomposed in components belonging to undoped $\mathrm{LPS}, \mathrm{Ce}^{3+}$ in $\mathrm{SiO}_{2}$ and $\mathrm{Ce}^{3+}$ in LPS (Fig. 27)

PL decay of LPS:Ce/ $\mathrm{SiO}_{2}$ nanocomposite sample annealed at $1300{ }^{\circ} \mathrm{C}$ is given in Fig. 28 . Leading decay time of $29 \mathrm{~ns}$ is slightly shorter compared to $32 \mathrm{~ns}$ found in LPS:Ce single crystal (Feng et al., 2010). It might be caused by the effect of small size of nanospheres of LPS:Ce and different refractive index of surrounding medium (Metzer et al., 1999). Slower decay tail of very low amplitude is of unclear origin. It could be related to $\mathrm{Ce}^{3+}$ ions close to LPS nanophase surface where e.g. tunneling from $5 d_{1}$ excited state of $\mathrm{Ce}^{3+}$ to a defect might exist. Scintillation decay of the same sample under the excitation by picosecond X-ray pulse is given in Fig. 29. The leading decay component of decay time $29.4 \mathrm{~ns}$ is perfectly consistent with that in PL decay in Fig. 28. In addition, there is slower decay process which overestimates the fit above $60-70 \mathrm{~ns}$ and must be due to the delayed recombination process arising in the transport stage of scintillator mechanism. 


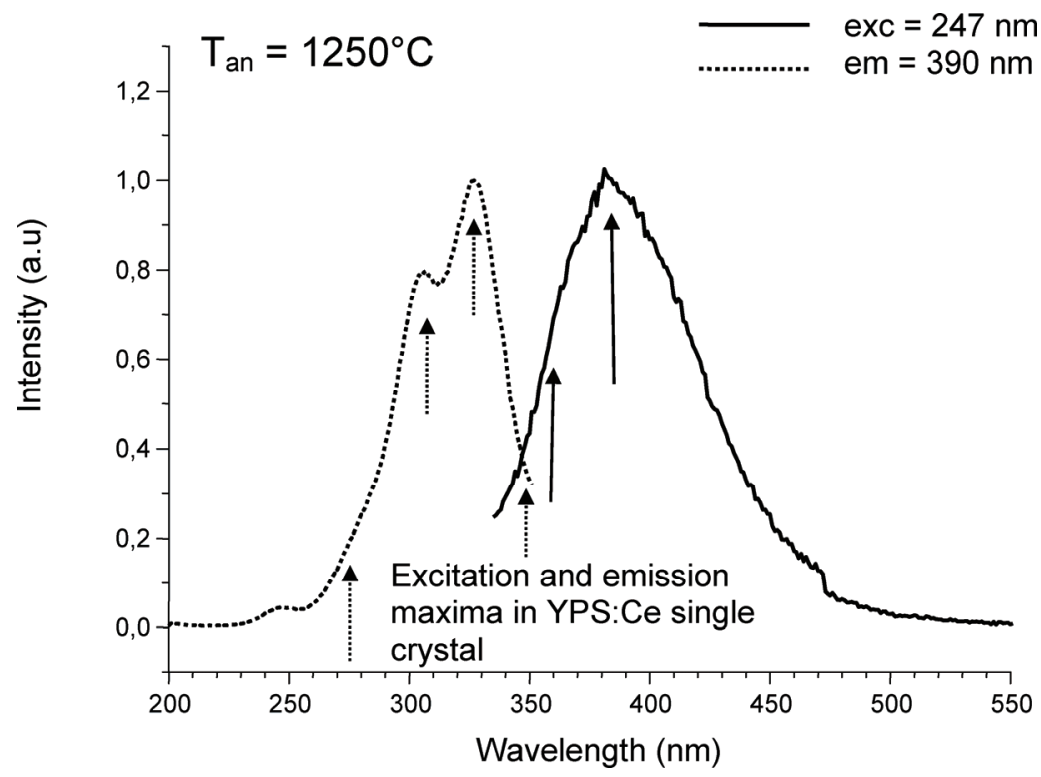

Fig. 24. PL (ex=247 nm) and PLE (em=390nm) spectra of YPS:Ce/SiO $\mathrm{A}_{2} 10$ sample at RT.

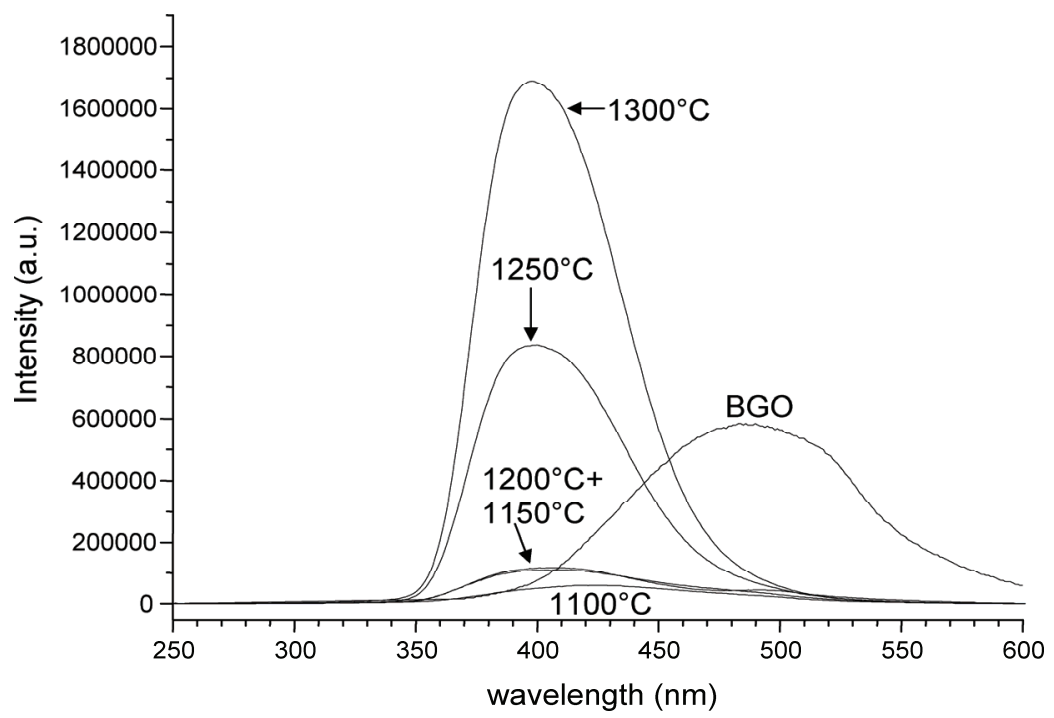

Fig. 25. RL spectra of LPS:Ce/ $\mathrm{SiO}_{2}$ nanocomposite sample annealed at different temperatures given in the figure. Excitation X-ray, $40 \mathrm{kV}$. 


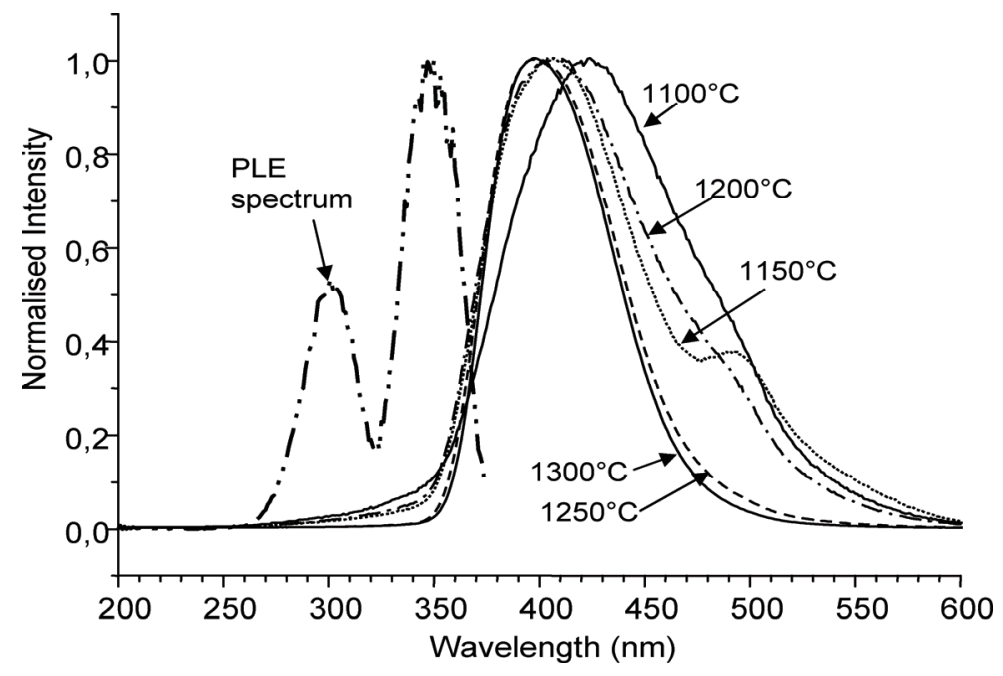

Fig. 26. Normalized RL spectra of LPS:Ce/ $\mathrm{SiO}_{2}$ nanocomposite samples from Fig. 25. Excitation X-ray, $40 \mathrm{kV}$. PLE spectrum for $\mathrm{T}_{\mathrm{an}}=1300^{\circ} \mathrm{C}$ and $\mathrm{em}=410 \mathrm{~nm}$ is shown as well

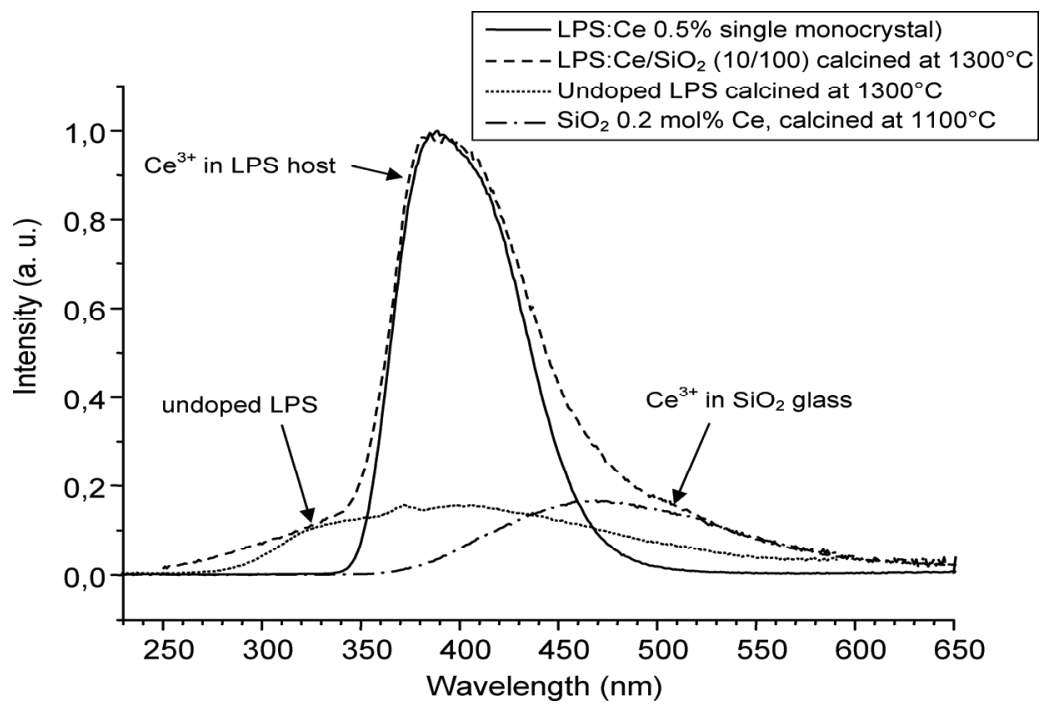

Fig. 27. Radioluminescence spectra (excitation X-ray, $40 \mathrm{kV}$ ) of LPS:Ce single crystal, LPS:Ce/ $\mathrm{SiO}_{2}$ nanocomposite, undoped LPS powder and $\mathrm{SiO}_{2}$ :Ce glass. The latter three samples were made by an analogous sol-gel route, single crystal was grown by Czochralski method (Feng et al., 2010) 


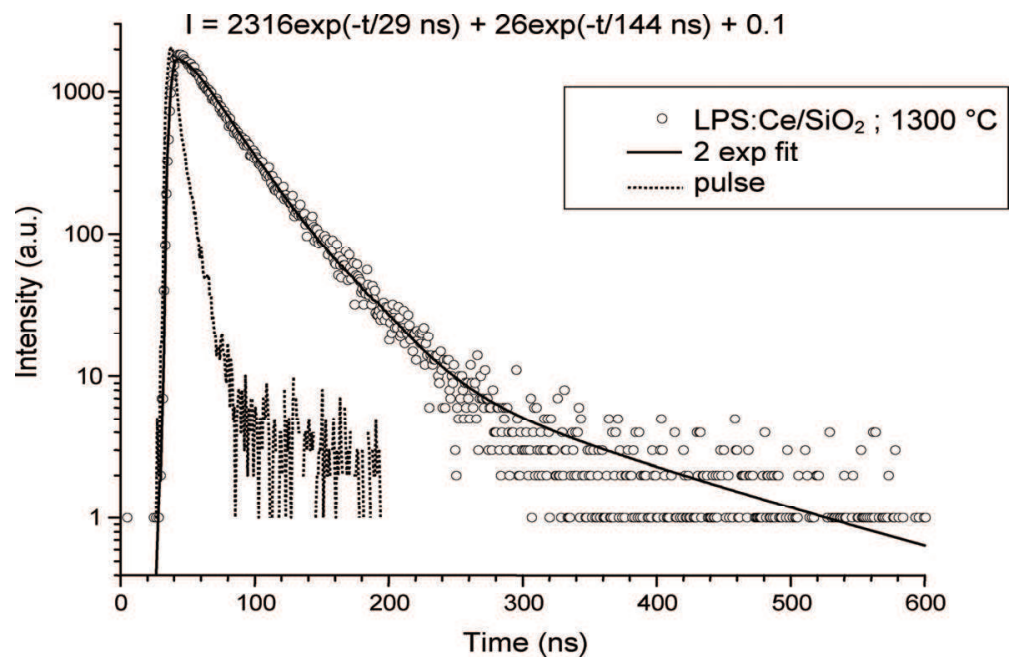

Fig. 28. PL decay of LPS:Ce/ $\mathrm{SiO}_{2}$ nanocomposite sample. Ex=300 nm, em=410 nm. Solid line is the fit $\mathrm{I}(\mathrm{t})$ given in the figure.

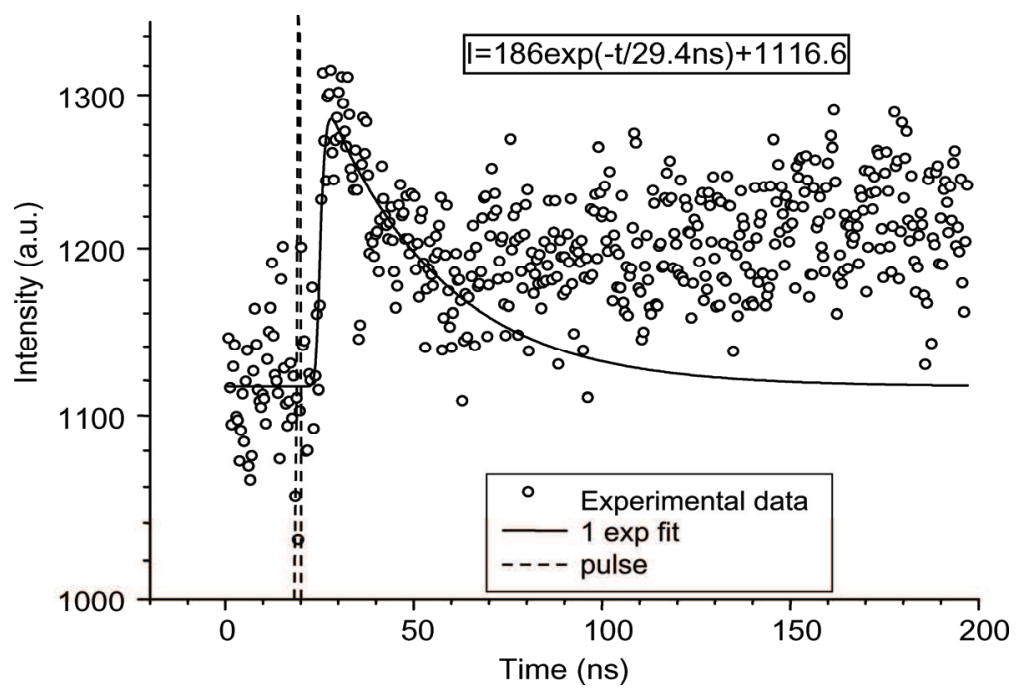

Fig. 29. Scintillation decay of LPS:Ce/ $\mathrm{SiO}_{2}$ nanocomposite sample. Excitation by picosecond X-ray pulse, for technical details see (Yanagida et al., 2010).

Following the procedure carried out at the Ce-doped silicate glasses (Chiodini et al., 2002) the samples of $\mathrm{SiO}_{2} / \mathrm{Lu}_{2} \mathrm{Si}_{2} \mathrm{O}_{7}$ nanocomposites annealed at $1000^{\circ} \mathrm{C}$ were rapidly heat-treated at temperature between $1600-2000{ }^{\circ} \mathrm{C}$. This rapid thermal treatment (RTT) consisted of 30 seconds heating period in the hydrogen-oxygen flame. The characterization by XRD showed that they remain amorphous after such a treatment. RL spectra of the samples show that the 
RTT strongly influences the shape, position and intensity of RL spectrum (Fig. 30). In (Chiodini et al., 2002) strong increase of scintillation efficiency was reported at Ce-doped silicate glass after RTT treatment. In our case, similar conclusion can be drawn for the highest RTT temperature of $2000{ }^{\circ} \mathrm{C}$, when the spectrum remains low energy shifted compared to the situation in the powder nanocomposite annealed at $1250-1300{ }^{\circ} \mathrm{C}$ (Fig. 26). This is consistent with the fact that LPS nanophase crystallized in the latter case while remaining amorphous after RTT procedure. RTT probably helps to form better $\mathrm{SiO}_{2}$ glass host which provides higher efficiency for charge carrier transport in the scintillation mechanism.

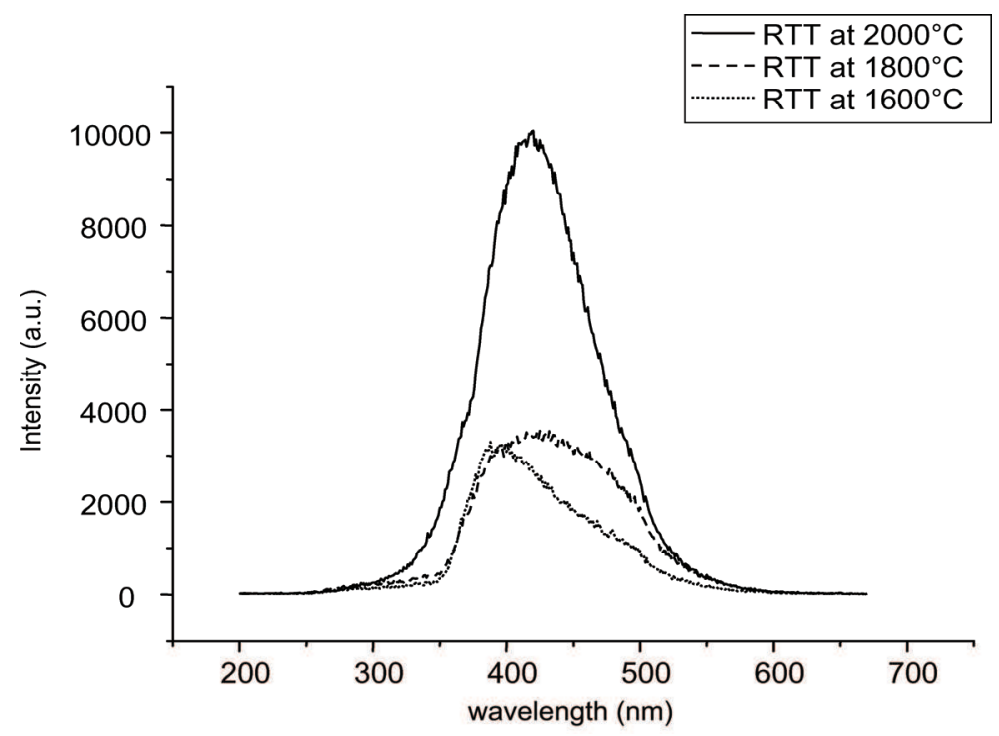

Fig. 30. RL spectra of LPS:Ce/ $\mathrm{SiO}_{2}$ nanocomposite sample after application of RTT procedure, the temperature of which is given in the legend

\section{Conclusions}

Sol-gel method has been successfully used for preparation of Ce-doped yttrium (YPS) and lutetium (LPS) pyrosilicates in powder form and of composite materials (REPS:Ce $)_{0.1^{-}}$ $\left(\mathrm{SiO}_{2}\right)_{0.9}, \mathrm{RE}=\mathrm{Y}, \mathrm{Lu}$. XRD measurements showed that the crystallization of YPS take the place at $1100^{\circ} \mathrm{C}$ in the case of pure powder sample while, in the case of nanocomposites, it is shifted to the range of $1200-1300^{\circ} \mathrm{C}$. Moreover, in the latter case, it is accompanied by simultaneous crystallization of $\mathrm{SiO}_{2}$ matrix leading to non-transparent samples. Nevertheless, this drawback (cristobalite formation, loss of transparency) could be partially overcome by RTT, because the kinetics of cristobalite formation is very slow. TEM images of (REPS:Ce $)_{0.1}-\left(\mathrm{SiO}_{2}\right)_{0.9}, \mathrm{RE}=\mathrm{Y}, \mathrm{Lu}$ revealed the regular round shapes nanoparticles in the silica matrix. Its average size increases with the temperature of heat treatment from $30 \mathrm{~nm}$ (heattreated at $1100^{\circ} \mathrm{C}$ ) to $100 \mathrm{~nm}$ (heat-treated at $1300^{\circ} \mathrm{C}$ ).

Luminescence spectra of powder YPS:Ce were found low energy shifted in comparison to the single crystal analogue which might be due to extensive perturbation of $\mathrm{Ce}^{3+}$ centers by 
the grain surface and structural flaws. LPS:Ce emission characteristics showed to be closer to the bulk single crystal.

Photo- and radioluminescence spectra of YPS:Ce and LPS:Ce crystallized nanophase in $\mathrm{SiO}_{2}$ host appeared very similar to their bulk single crystal analogs. Slightly shortened $\mathrm{Ce}^{3+}$ decay times in REPS:Ce/SiO 2 can indicate the effect of small size of REPS:Ce nanospheres and different refractive index of surrounding medium. RTT leaves the pyrosilicate phase amorphous although the luminescence efficiency increases noticeably, small low energy shift of $\mathrm{Ce}^{3+}$ spectrum is consistent with the amorphous character of REPS host. RTT procedure indicates the possibility to obtain transparent bulk optical elements with scintillating REPS:Ce nanophase, but more experimental work has to be done to achieve good transparency and crack-free samples.

\section{Acknowledgement}

The support of Grant Agency of AS CR, project KAN300100802 is gratefully acknowledged. Thanks are due to A. Beitlerova, R. Kucerkova and V. Jary for luminescence measurements. V.Tyrpekl and I.Jakubec are acknowledged for SEM, TEM and HRTEM photographs. CRYTUR Ltd. and P. Horodysky are acknowledged for technical help in the experiments.

\section{References}

Becquerel, H. (1896). Sur les Radiations Invisibles Emises par les Corps Phosphorescents. Comptes-Rendus Hebdomadaires des Séances de l'Académie des Sciences, Vol. 122, pp. 501-503.

Bihari, B.; Eilers, H. \& Tissue, B. M. (1997). Spectra and Dynamics of Monoclinic $\mathrm{Eu}_{2} \mathrm{O}_{3}$ and $\mathrm{Eu}^{3+}: \mathrm{Y}_{2} \mathrm{O}_{3}$ Nanocrystals. Journal of Luminescence, Vol. 75, No. 1, (July 1997), pp. 1-10, ISSN 0022-2313

Bretheau-Raynal, F.; Tercier, N. \& Blanzat, B. (1980). Synthesis and Spectroscopic Study of Lutetium Pyrosilicate Single Crystals Doped with Trivalent Europium. Materials Research Bulletin, Vol. 15, No. 5, (May 1980), pp. 639-646, ISSN 0025-5408

Brinker, C. J. \& Scherer, G. W. (1990). Sol-Gel Science: The Physics and Chemistry of Sol-Gel Processing, Academic Press, ISBN 978-0121349707, San Diego

Chen, W.; Zhang, J., Wescott, S. L., Joly, A. G., Malm, J.-O. \& Bovin, J.-O. (2006). The Origin of X-Ray Luminescence from CdTe Nanoparticles in CdTe/BaFBr:Eu ${ }^{2+}$ Nanocomposite Phosphors. Journal of Applied Physics, Vol. 99, No. 3, (1 Feb 2006), p. 034302 (5 pages), ISSN 0021-8979

Chiodini, N.; Fasoli, M., Martini, M., Rosetta, E., Spinolo, G., Vedda, A., Nikl, M., Solovieva, N., Baraldi, A. \& Capelletti, R. (2002). High-Efficiency $\mathrm{SiO}_{2}: \mathrm{Ce}^{3+}$ Glass Scintillators. Applied Physics Letters, Vol. 81, No. 23 (2 Dec 2002), pp. 4374-4376, ISSN 0003-6951

Coetsee, E.; Swart, H. C. \& Terblans, J. J. (2007). Cathodoluminescence Degradation of $\mathrm{Y}_{2} \mathrm{SiO}_{5}: \mathrm{Ce}$ Thin Films. Journal of Vacuum Science and Technology A, Vol. 25, No. 4, (July 2007), pp. 1226-1230, ISSN 0734-2101

Cooke, D. W.; McClellan, K. J., Bennett, B. L., Roper, J. M., Whittaker, M. T., Muenchausen, R. E. \& Sze, R. C. (2000). Crystal Growth and Optical Characterization of CeriumDoped $\mathrm{Lu}_{1.8} \mathrm{Y}_{0.2} \mathrm{SiO}_{5}$, Journal of Applied Physics, Vol. 88, No. 12, (15 Dec 2000), pp. 7360-7362, ISSN 0021-8979

Cooke, D. W.; Lee, J.-K., Bennett, B. L., Groves, J. R., Jacobsohn, L. G., McKigney, E. A., Muenchausen, R. E., Nastasi, M., Sickafus, K. E., Tang, M. J. \& Valdez, A. (2006). 
Luminescent Properties and Reduced Dimensional Behavior of Hydrothermally Prepared $\mathrm{Y}_{2} \mathrm{SiO}_{5}$ :Ce Nanophosphors. Applied Physics Letters, Vol. 88, No. 10, 6 Mar), p. 103108 (3 pages), ISSN 0003-6951

Curie, M. (1898). Rayons Emises par les Composes de l'Uranium et du Thorium, ComptesRendus Hebdomadaires des Séances de l'Académie des Sciences, Vol. 126, pp. 1101-1103

Dias, W.; Glasser, F. P., Gunwardane, R. P. \& Howie, R. A. (1990). The Crystal Structure of $\delta$ Yttrium Pyrosilicate, $\delta-\mathrm{Y}_{2} \mathrm{Si}_{2} \mathrm{O}_{7}$. Zeitschrift für Kristallographie, Vol. 191, No. 1-2, (January 1990), pp. 117-123, ISSN 0044-2968

Feng, H.; Ding, D., Li, H., Lu, S., Pan, S., Chen, X. \& Ren, G. (2010). Growth and Luminescence Characteristics of Cerium-Doped Yttrium Pyrosilicate Single Crystal. Journal of Alloys and Compounds, Vol. 489, No. 2, (21 Jan 2010), pp. 645-649, ISSN 0925-8388

Goldburt, E. T.; Kulkarni, B., Bhargava, R. N., Taylor, J. \& Libera, M. (1997). Size Dependent Efficiency in Tb Doped $\mathrm{Y}_{2} \mathrm{O}_{3}$ Nanocrystalline Phosphor. Journal of Luminescence, Vol. 72-74, (June 1997), pp. 190-192, ISSN 0022-2313

Gonzalez-Ortega, J. A.; Tejeda, E. M., Perea, N., Hirata, G. A., Bosze, E. J. \& McKittrick, J. (2005). White Light Emission from Rare Earth Activated Yttrium Silicate Nanocrystalline Powders and Thin Film. Optical Materials, Vol. 27, No. 7, (April 2005), pp. 1221-1227, ISSN 0925-3467

Greskovich, C. \& Duclos, S. (1997). Ceramic Scintillators. Annual Review of Materials Science, Vol. 27, (August 1997), pp. 69-88, ISSN 0084-6600

Holloway, P. H.; Trottier, T. A., Abrams, B., Kondoleon, C., Jones, S. L., Sebastian, J. S., Thomes, W. J. \& Swart, H. (1999). Advances in Field Emission Displays Phosphors. Journal of Vacuum Science and Technology B, Vol. 17, No. 2, (March 1999), pp. 758-764, ISSN 1071-1023

Jiao, H.; Wei, L. Q., Zhang, N., Zhong, M. \& Jing, X. P. (2007). Melting Salt Assisted Sol-Gel Synthesis of Blue Phosphor $\mathrm{Y}_{2} \mathrm{SiO}_{5}$ :Ce. Journal of the European Ceramic Society, Vol. 27, No. 1, (2007), pp. 185-189, ISSN 0955-2219

Johnson, J. A.; Schweizer, S., Henke, B., Chen, G., Woodford, J., Newman, P. J. \& Macfarlane, D. R. (2006). Eu-Activated Fluorochlorozirconate Glass-Ceramic Scintillators. Journal of Applied Physics, Vol. 100, No. 3, (1 Aug 2006), p. 034701 (5 pages), ISSN 0021-8979

Kang, Y. C.; Lenggoro, I. W., Park, S. B. \& Okuyama, K. (1999). Y $2 \mathrm{SiO}_{5}$ :Ce Phosphor Particles $0.5-1.4 \mu \mathrm{m}$ in Size with Spherical Morphology. Journal of Solid State Chemistry, Vol. 146, No. 1, (August 1999), pp. 168-175, ISSN 0022-4596

Krell, A.; Klimke, J. \& Hutzler, T. (2009). Transparent Compact Ceramics: Inherent Physical Issues. Optical Materials, Vol. 31, No. 8, (June 2009), pp. 1144-1150, ISSN 0925-3467

Leonyuk, H. I.; Belokoneva, E. L., Bocelli, G., Righi, L., Shvanskii, E. V., Henrykhson, R. V., Kulman, N. V. \& Kozhbakhteeva, D. E. (1999). High-Temperature Crystallization and X-Ray Characterization of $\mathrm{Y}_{2} \mathrm{SiO}_{5}, \mathrm{Y}_{2} \mathrm{Si}_{2} \mathrm{O}_{7}$ and $\mathrm{LaBSiO}_{5}$, Journal of Crystal Growth, Vol. 205, No. 3, (September 1999), pp. 361-367, ISSN 0022-0248

Létant, S. E. \& Wang, T.-F. (2006a). Study of Porous Glass Doped with Quantum Dots or Laser Dyes under Alpha Irradiation. Applied Physics Letters, Vol. 88, No. 10, (6 Mar 2006), p. 103110 (3 pages), ISSN 0003-6951

Létant, S. E. \& Wang, T.-F. (2006b). Semiconductor Quantum Dot Scintillation under $\gamma$-Ray Irradiation. Nano Letters, Vol. 6, No. 12, (December 2006), pp. 2877-2880, ISSN 15306984 
Liddell, K. \& Thompson, D. P. (1986). X-Ray Diffraction Data for Yttrium Silicates. British Ceramic, Transactions and Journal, Vol. 85, No. 1, (January-February 1986), pp. 17-22, ISSN 0266-7606

Louis, C.; Bazzi, R., Flores, M.A., Zheng, W., Lebbou, K., Tillement, O., Mercier, B., Dujardin, C. \& Perriat, P. (2003). Synthesis and Characterization of $\mathrm{Gd}_{2} \mathrm{O}_{3}: \mathrm{Eu}^{3+}$ Phosphor Nanoparticles by a Sol-Lyophilization Technique. Journal of Solid State Chemistry, Vol. 173, No. 2, (July 2003), pp. 335-341, ISSN 0022-4596

Marsh, P. J.; Silver, J., Vecht, A. \& Newport, A. (2002). Cathodoluminescence Studies of Yttrium Silicate:Cerium Phosphors Synthesised by a Sol-Gel Process. Journal of Luminescence, Vol. 97, No. 3-4, (June 2002), pp. 229-236, ISSN 0022-2313

Meijerink, A.; Schipper, W. J. \& Blasse, G. (1991). Photostimulated Luminescence and Thermally Stimulated Luminescence of $\mathrm{Y}_{2} \mathrm{SiO}_{5}: \mathrm{Ce}, \mathrm{Sm}$. Journal of Physics D, Vol. 24, No. 6, (June 1991), pp. 997-1002, ISSN 0022-3727

Melcher, C. L.; Manente, R. A., Peterson, C. A. \& Schweitzer, J. S. (1993). Czochralski Growth of Rare Earth Oxyorthosilicate Single Crystals. Journal of Crystal Growth, Vol. 128, No. 1-4 Part 2, (1 March 1993), pp. 1001-1005, ISSN 0022-0248

Meltzer, R. S.; Jang, K. W., Hong, K. S., Sun, Y. \& Feofilov, S. P. (1997). Optical Dephasing of Rare Earth Ions in Mixed Crystalline and Size-Restricted Systems. Journal of Alloys and Compounds, Vol. 250, No. 1-2, (20 March, 1997) pp. 279-286, ISSN 0925-8388

Meltzer, R. S.; Feofilov, S. P., Tissue, B. \& Yuan, H. B. (1999). Dependence of Fluorescence Lifetimes of $\mathrm{Y}_{2} \mathrm{O}_{3}: \mathrm{Eu}^{3+}$ Nanoparticles on the Surrounding Medium. Physical Review B, Vol. 60, No. 20, (15 November 1999), pp. R14012-R14015, ISSN 1098-0121

Mercier, B.; Dujardin, C., Ledoux, G., Luis, C., Tillement, O. \& Perriat, P. (2004). Observation of the Gap Blueshift on $\mathrm{Gd}_{2} \mathrm{O}_{3}: \mathrm{Eu}^{3+}$ Nanoparticles. Journal of Applied Physics, Vol. 96, No. 1, (1 July 2004), pp. 650-653, ISSN 0021-8979

Mercier, B.; Dujardin, C., Ledoux, G., Louis, C., Tillement, O. \& Perriat, P. (2006). Confinement Effects in Sesquioxydes. Journal of Luminescence, Vol. 119-120, (JulyOctober 2006) pp. 224-227, ISSN 0022-2313

Mercier, B.; Ledoux, G., Dujardin, C., Nicolas, N., Masenelli, B., M'elinon, P. \& Bergeret, G. (2007). Quantum Confinement Effect on $\mathrm{Gd}_{2} \mathrm{O}_{3}$ Clusters. Journal of Chemical Physics, Vol. 126, No. 4, (28 January 2007), p. 044507 (7 pages), ISSN 0021-9606

Muenchausen, R. E.; Jacobsohn, L. G., Bennet, B. L., McKigney, E. A., Smith, J. F., Valdez , J. A. \& Cooke, D. W. (2007). Effects of Tb Doping on the Photoluminescence of $\mathrm{Y}_{2} \mathrm{O}_{3}: \mathrm{Tb}$ Nanophosphors. Journal of Luminescence, Vol. 126, No. 2, (October 2007), pp. 838-842, ISSN 0022-2313

Niznansky, D. \& Rehspringer, J. L. (1995). Infrared Study of $\mathrm{SiO}_{2}$ Sol to Gel Evolution and Gel Aging. Journal of Non-Crystalline Solids, Vol. 180, No. 2-3, (January1995), pp. 191196, ISSN 0022-3093

Niznansky, D.; Lančok, A., Hutlová, A., Bursik, J. \& Rehspringer, J.-L. (2001). Preparation of $\mathrm{Y}_{3} \mathrm{Fe}_{5} \mathrm{O}_{12}$ Nanocomposites by Sol-Gel Method: Influence of Modifiers. International Journal of Inorganic Materials, Vol. 3, No. 6, (September 2001), pp. 479-483, ISSN 1466-6049

Pauwels, D.; Le Masson, N., Viana, B., Kahn-Harari, A., van Loef, E. V. D., Dorenbos, P. \& van Eijk, C. W. E. (2000). A novel Inorganic Scintillator: $\mathrm{Lu}_{2} \mathrm{Si}_{2} \mathrm{O}_{7}: \mathrm{Ce}^{3+}$ (LPS). IEEE Transactions on Nuclear Science, Vol. 47, No. 6, (December 2000), pp. 1787-1790, ISSN 0018-9499 
Pedrini, C.; Moine, B., Gacon, J. C. \& Jacquier, B. (1992). One- and Two-Photon Spectroscopy of $\mathrm{Ce}^{3+}$ Ions in $\mathrm{LaF}_{3}-\mathrm{CeF}_{3}$ Mixed Crystals. Journal of Physics: Condensed Matter, Vol. 4, No. 24, (15 June 1992), pp. 5461-5470, ISSN 0953-8984

Pidol, L.; Viana, B., Bessière, A., Galtayries, A., Dorenbos, P. \& Ferrand, B. (2007). High Efficiency of Lutetium Silicate Scintillators, Ce-Doped LPS and LYSO Crystals for Medical Applications. Materials Science Forum, Vol. 555, (2007), pp. 371-376, ISSN 0255-5476

Redhammer, G. J. \& Roth, G. (2003). $\beta-\mathrm{Y}_{2} \mathrm{Si}_{2} \mathrm{O}_{7}$, A New Thortveitite-Type Compound, Determined at 100 and 280 K. Acta Crystallographica C, Vol. 59, No. 10, (October 2003), pp. i103-i106, ISSN 0108-2701

Röntgen, W. C. (1896). On a New Kind of Rays. Science, Vol. 3, No. 59, (14 February 1896), pp. 227-231.

Shibuya, K.; Koshimizu, M., Murakami, H., Muroya, Y., Katsumura, Y. \& Asai, K. (2004). Development of Ultra-Fast Semiconducting Scintillators Using Quantum Confinement Effect. Japanese Journal of Applied Physics, Vol. 43, Part 2, No. 10B, (15 October 2004), pp. L1333-L1336, ISSN 0021-4922

Soetebier, F. \& Urland, W. (2002). Crystal Structure of Lutetium Disilicate $\mathrm{Lu}_{2} \mathrm{Si}_{2} \mathrm{O}_{7}$. Zeitschrift für Kristallographie - New Crystal Structure, Vol. 217, No. 1, (2002), p. 22 , ISSN 1433-7266

Sokolnicki, J. \& Guzik, M. (2009). Synthesis and Photoluminescence of Nanocrystalline Lutetium Pyrosilicate Doped with Ce3+. Optical Materials, Vol. 31, No. 6, (April 2009), pp. 826-830, ISSN 0925-3467

Suzuki, H.; Tombrello, T. A., Melcher, C. L. \& J. S. Schweitzer, J. S. (1992). UV and GammaRay Excited Luminescence of Cerium-Doped Rare-Earth Oxyorthosilicates, Nuclear Instruments and Methods in Physics Research Section A: Accelerators, Spectrometers, Detectors and Associated Equipment, Vol. 320, No. 1-2, (15 August 1992), pp. 263-272, ISSN 0168-9002

Takagi, K. \& Fukazawa, T. (1983). Cerium-Activated $\mathrm{Gd}_{2} \mathrm{SiO}_{5}$ Single Crystal Scintillator. Applied Physics Letters, Vol. 42, No. 1, (1 January 1983), pp. 43-45, ISSN 0003-6951

Tissue, B. M. (1998). Synthesis and Luminescence of Lanthanide Ions in Nanoscale Insulating Hosts. Chemistry of Materials, Vol. 10, No. 10, (October 1998), pp. 28372845, ISSN 0897-4756

Vakhidov, S. A.; Ibragimova, E. M., Nuritdinov, I., Rakov, A. F. \& Ikramov, G. I. (1981). SelfTrapped Particles in Complex Oxide Crystals. Physica Status Solidi B, Vol. 106, No. 1, (July 1981), pp. 31-35, ISSN 0370-1972

van Eijk, C. W. E. (2002). Inorganic Scintillators in Medical Imaging. Physics in Medicine and Biology, Vol. 47, No. 8, (21 April 2002), pp. R85-R106, ISSN 0031-9155

Weber, M. J. (2002). Inorganic Scintillators: Today and Tomorrow. Journal of Luminescence, Vol. 100, No. 1-4, (December 2002), pp. 35-45, ISSN 0022-2313

Yan, C.; Zhao, G., Hang, Y., Zhang, L. \& Xu, J. (2006). Czochralski growth and crystal structure of cerium-doped $\mathrm{Lu}_{2} \mathrm{Si}_{2} \mathrm{O}_{7}$ scintillator. Materials Letters, Vol. 60, No. 16, (July 2006), pp. 1960-1963, ISSN 0167-577X

Yanagida, T.; Fujimoto, Y., Yoshikawa, A., Yokota, Y., Kamada, K., Pejchal, J., Kawaguchi, N., Ishizu, S., Fukuda, K., Suyama, T., Uchiyama, K., Mori, K., Kitano, K. \& Nikl, M. (2010). Development and Performance Test of Picosecond Pulse X-Ray Excited Streak Camera System for Scintillator Characterization. Applied Physics Express, Vol. 3, No. 5, (May 2010), pp. 056202 (3 pages), ISSN 1882-0778 


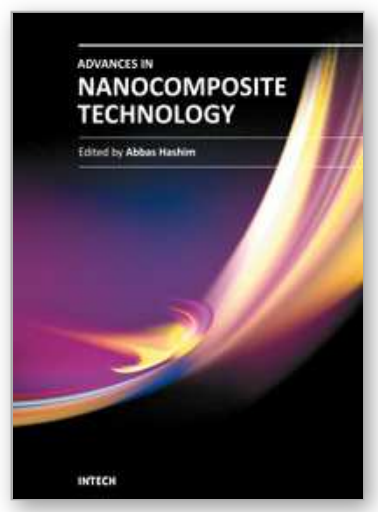

\author{
Advances in Nanocomposite Technology \\ Edited by Dr. Abbass Hashim
}

ISBN 978-953-307-347-7

Hard cover, 374 pages

Publisher InTech

Published online 27, July, 2011

Published in print edition July, 2011

The book â€œAdvances in Nanocomposite Technologyâ€ contains 16 chapters divided in three sections. Section one, â€œElectronic Applicationsâ€, deals with the preparation and characterization of nanocomposite materials for electronic applications and studies. In section two, â€œMaterial Nanocompositesâ€, the advanced research of polymer nanocomposite material and polymer-clay, ceramic, silicate glass-based nanocomposite and the functionality of graphene nanocomposites is presented. The â€œHuman and Bioapplicationsâ€ section is describing how nanostructures are synthesized and draw attention on wide variety of nanostructures available for biological research and treatment applications. We believe that this book offers broad examples of existing developments in nanocomposite technology research and an excellent introduction to nanoelectronics, nanomaterial applications and bionanocomposites.

\title{
How to reference
}

In order to correctly reference this scholarly work, feel free to copy and paste the following:

Martin Nikl, Daniel Niž?anský, Jakub Ruzicka, Carla Cannas and Takayuki Yanagida (2011). Silicate GlassBased Nanocomposite Scintillators, Advances in Nanocomposite Technology, Dr. Abbass Hashim (Ed.), ISBN: 978-953-307-347-7, InTech, Available from: http://www.intechopen.com/books/advances-in-nanocompositetechnology/silicate-glass-based-nanocomposite-scintillators

\section{INTECH}

open science | open minds

\author{
InTech Europe \\ University Campus STeP Ri \\ Slavka Krautzeka 83/A \\ 51000 Rijeka, Croatia \\ Phone: +385 (51) 770447 \\ Fax: +385 (51) 686166 \\ www.intechopen.com
}

\author{
InTech China \\ Unit 405, Office Block, Hotel Equatorial Shanghai \\ No.65, Yan An Road (West), Shanghai, 200040, China \\ 中国上海市延安西路65号上海国际贵都大饭店办公楼 405 单元 \\ Phone: +86-21-62489820 \\ Fax: +86-21-62489821
}


(C) 2011 The Author(s). Licensee IntechOpen. This chapter is distributed under the terms of the Creative Commons Attribution-NonCommercialShareAlike-3.0 License, which permits use, distribution and reproduction for non-commercial purposes, provided the original is properly cited and derivative works building on this content are distributed under the same license. 